\title{
Biorefinery strategies for upgrading Distillers' Dried Grains with Solubles (DDGS)
}

Article

Accepted Version

Chatzifragkou, A., Kosik, O., Prabhakumari, P. C., Lovegrove, A., Frazier, R., Shewry, P. R. and Charalampopoulos, D. (2015) Biorefinery strategies for upgrading Distillers' Dried Grains with Solubles (DDGS). Process Biochemistry, 50 (12). pp. 2194-2207. ISSN 0032-9592 doi:

https://doi.org/10.1016/j.procbio.2015.09.005 Available at https://centaur.reading.ac.uk/42472/

It is advisable to refer to the publisher's version if you intend to cite from the work. See Guidance on citing.

To link to this article DOI: http://dx.doi.org/10.1016/j.procbio.2015.09.005

Publisher: Elsevier

All outputs in CentAUR are protected by Intellectual Property Rights law, including copyright law. Copyright and IPR is retained by the creators or other copyright holders. Terms and conditions for use of this material are defined in the End User Agreement. 


\section{CentAUR}

Central Archive at the University of Reading

Reading's research outputs online 
(DDGS)

$4 \quad$ Afroditi Chatzifragkou ${ }^{1 *}$, Ondrej Kosik ${ }^{2}$, Parvathy Chandran Prabhakumari ${ }^{1}$, Alison Lovegrove ${ }^{2}$,

${ }^{1}$ Department of Food and Nutritional Sciences, University of Reading, Whiteknights, PO Box 226, Reading, RG6 6AP, UK

9

${ }^{2}$ Department of Plant Science, Rothamsted Research, Harpenden, AL5 2JQ, Hertfordshire, UK 10 
20 Abstract

Distillers' Dried Grains with Solubles (DDGS) is the major by-product of bioethanol and distillery plants. Due to its high content of proteins, water-soluble vitamins and minerals, DDGS has been 24 long marketed as animal feed for livestock. EU legislation on liquid biofuels could raise the 25 demand on bioethanol production in Europe, with a resulting increase in DDGS availability. DDGS contains a spectrum of complex organic macromolecules, particularly polysaccharides, in addition to proteins and vitamins, and its use as a starting raw material within a biomass-based biorefining strategy could lead to the development of multi-stream processes for the production of commodities, platform molecules or speciality chemicals, with concomitant economic benefits and waste reduction for bioethanol plants. The present review aims to outline the compositional characteristics of DDGS and evaluate its potential utilisation as a starting material for the production of added-value products. Parameters of influence on the chemical and physical characteristics of DDGS are discussed. Moreover, various pre-treatment strategies are outlined in terms of efficient DDGS fractionation into several added value streams. Additional processing steps for the production of medium and high added value compounds from DDGS are evaluated and their potential applications in the food and chemical industry sector are identified. 


\section{Introduction}

Bioethanol represents one of the most important biofuels for automotive transportation. In 2013, global bioethanol production reached 88 billion litres, with economic projections estimating further increases in annual production until 2020 [1]. US contributions account for almost half of the total worldwide bioethanol production, followed by Brazil and European Union (EU). On the basis of feedstock, the USA and EU produce bioethanol through the utilisation of grains (maize and wheat, respectively), while Brazilian plants employ sugar cane as raw material. Based on the OECD-FAO Agricultural Outlook for 2011-2020, the major producers of grain-based ethanol are USA, Canada and the EU.

The production of grain-based ethanol results in the generation of distillers dried grains with solubles (DDGS) as a by-product. A schematic representation of the dry grind bioethanol production process and by-product streams is given in Figure 1. Briefly, the whole grain is milled and liquefied, while the addition of amylolytic enzymes facilitates the conversion of starch into fermentable glucose. Then, yeast is added to ferment the available carbon into ethanol and carbon dioxide. Ethanol is distilled and dehydrated, whereas the non-volatile components are centrifuged to produce a liquid fraction (thin stillage, TS) and a solid fraction (wet distillers' grains, WDG). Around $15 \%$ or more of the thin stillage is used as backset (i.e. added to the new batch) for the liquefaction of the ground grain and the rest is concentrated into condensed distiller soluble (CDS). CDS is mixed with WDG and drum dried at high temperatures to produce the final DDGS. Partial recycling of DDGS to the drum dryer is also a common practice in the ethanol industry, in order to increase the drying efficiency of the equipment [2]. It is estimated that in the dry milling process, the utilization of $100 \mathrm{~kg}$ of grain results in 40.2 litres of ethanol, $32.3 \mathrm{~kg}$ of DDGS and $32.3 \mathrm{~kg}$ of $\mathrm{CO}_{2}$. As far as global bioethanol derived DDGS production is concerned, OECD-FAO 
projections estimate that the USA will reach 44 million tonnes by 2018, whereas EU and Canada contributions are expected to be equal to nine and one million tonnes, respectively [3].

Another industry that contributes to the global surplus of DDGS is the beverage alcohol industry (e.g. distilleries for whisky and other spirits). The production process is similar to that of dry grind bioethanol, although considerable emphasis is placed on Good Manufacturing Practices and hygiene aspects since the final product (potable ethanol) is intended directly for human consumption. It is also worth noting that grain whisky distilleries often utilise blended grains as raw materials that may include wheat, barley, maize and rye. As a result, the final composition of DDGS may vary more than that of strictly corn or wheat derived DDGS.

DDGS has been recognised as an important source of energy, protein, water-soluble vitamins and minerals and for this reason it has been long marketed as feed for livestock [4, 5]. This exploitation contributes significantly to the profitability of distillery and bioethanol plants. In 2014, the annual market price for wheat DDGS in the United Kingdom averaged around $£ 230$ per tonne, while the respective price for maize DDGS the same year, mainly produced in the USA, was within the range of \$225-240 per tonne (source UK Home Grown Cereal Authorities-HCGA). During the first quarter of 2015, around 49.5 thousand tonnes of distillery by-products were used for the production of animal feed in the UK, increased by $46 \%$ compared to the first quarter of 2014 as reported by the UK Department for Environmental Food and Rural Affairs [6].

The production of bioethanol as "first generation" biofuel is likely to rise in future years in Europe as the Directive of EU regulatory framework for biofuels [7] requires that $10 \%$ of the energy used in transport should be of a renewable nature by 2020, the majority of which is anticipated to correspond to liquid biofuels. This fact is likely to increase the demand on bioethanol in Europe 
with a resulting increase in DDGS availability. Moreover, it is of importance to state that the addition of DDGS to livestock feed can account for up to $30 \%$ (dry matter basis) of the diet, as higher levels may cause palatability and excessive protein consumption issues [5]. Additionally, the compositional variation in DDGS in relation to its nutritional value and quality still constitutes an obstacle to its primary use as animal feed supplement for ruminants [8, 9]. Taking these into account, the need to find alternative routes to exploit and upgrade DDGS can be considered imperative. In 2011, the Integrated Biorefining Research and Technology Club (IBTI) of the UK Biotechnology and Biological Sciences Research Council (BBSRC) awarded in excess of $£ 2.5 \mathrm{M}$ in research grants as part of an initiative to identify alternative ways to enhance the value of DDGS. Moreover, earlier in 2010, the Home Grown Cereals Authority (HGCA) in UK co-funded a collaborative 3-year project named ENBBIO LINK, aiming to identify routes to improve the nutritional value of DDGS as feed for both ruminant and non-ruminant species.

DDGS contains a spectrum of complex organic macromolecules, such as carbohydrates, proteins and oil. Its incorporation as a starting raw material within a biomass-based biorefining strategy could therefore lead to the development of multi-stream processes for the production of commodities, platform molecules or specialty chemicals, with concomitant economic benefits and waste reduction for bioethanol plants. The scope of the present review is to outline the characteristics of DDGS, with respect to its components, and investigate its potential utilisation for the production of added-value products, within a biorefinery concept.

\section{Chemical composition of DDGS}

\subsection{Compositional variation of DDGS}

The composition of DDGS is of great interest, particularly in relation to animal nutrition. To this end, parameters such as nutrient composition, digestibility, and amino acid and mineral profiles 
have been investigated by a number of research groups $[10,11,12]$. The nutrient contents of DDGS have been reported to vary according to the nature of the raw material, e.g. wheat or maize, but also among production plants or even between batches from the same plant [13]. This variation can be directly correlated with compositional differences in the wheat and maize grains, the growing, harvesting and handling conditions of grains, but also with the addition of distillers' solubles in the dried grains, and the dehydration process as applied by each manufacturer $[2,14]$.

A summary of representative studies on the chemical composition of DDGS deriving from various starting materials is presented in Table 1. In the case of maize and wheat DDGS, a comparison of their chemical characteristics often reveals differences in the percentages of oil, protein, as well as in acid and neutral detergent fibre (ADF and NDF, respectively) (Table 1). Maize bioethanol DDGS is often richer in oil (11-15\%, w/w) compared to wheat bioethanol DDGS (4-6\%, w/w), although in both cases the lignin content is low (3-5\%, w/w) and is often expressed as acid detergent fibre (ADF), including the recalcitrant cellulose $[12,15]$. On the other hand, distillery DDGS can be differentiated in terms of its protein and NDF content, mainly due to the fact that distillery plants utilise blended grains, such as wheat, barley, maize and rye, instead of a single type of grain. Therefore, the choice of the starting material is a determinant factor for the final DDGS composition. Additionally, variation in the production process of DDGS between plants directly affects the chemical composition of the by-product. Spiehs et al. [16] investigated the variation in the composition of maize DDGS from ten ethanol plants in Minnesota and South Dakota. The coefficients of variation for protein, oil and crude fibre were reported to be lower than $10 \%$, whereas even less variation was estimated for dry matter. Variation in the nutrient content of DDGS was mostly attributed to the maize grain used, the percentage of solubles added back to distillers' dried grains, as well as to possible deviations from the standard practices followed during the fermentation process. As far as wheat DDGS composition is concerned, Jarret 
et al. [17] characterized the chemical composition of wheat DDGS samples supplied by seven

144 European ethanol plants. Differences in the origin and process of biofuel production between

145 plants were directly related to the variation in the percentage of fibre (NDF and ADF) and to 146 possible Maillard reactions taking place during the process. Furthermore, Cromwell et al. [14] 147 compared seven sources of DDGS deriving from beverage alcohol manufacturers and two sources 148 of DDGS from bioethanol plants, in order to evaluate their nutritional value for non-ruminants. 149 Physical characteristics, such as odour and colour, reflected differences in the drying processes and were directly correlated with the nutritional properties of DDGS, whereas notable variation was identified in terms of the oil, fibre and ash contents between samples which could be attributed to grain variety. In another study, Pedersen et al. [18] reported the compositional variation in DDGS from various bioethanol plants, including maize, wheat and mixed DDGS 154 (containing wheat, triticale, barley and rye, in unknown proportions). Maize DDGS presented 155

\subsection{Effect of processing on DDGS chemical composition}

From a processing point of view, it has been demonstrated that the mixing ratio of wet distillers' grains (WDG) and condensed distillers' soluble (CDS) can considerably affect the chemical composition of the DDGS $[2,19]$. The removal of starch during the fermentation step, as well as the thermal treatment of CDS and WDG, can lead to an approximately 3-fold concentration of the remaining macromolecules in DDGS, such as carbohydrates, protein and oil, whereas the inorganic content can be also substantially increased during the production process [20]. Generally, WDG contains higher amounts of insoluble fibre, whereas CDS contains soluble oligosaccharides, ash, as well as organic acids and glycerol generated as by-products during the 
ethanol fermentation process $[2,13]$. In terms of insoluble carbohydrates, it has been reported that after completion of the fermentation, more than $60 \%$ of the initial water-insoluble glucan from cellulose is left in WGD, whereas for hemicellulosic components, approximately $55 \%$ of the initial xylan and $65 \%$ of the initial arabinan remained in the insoluble fraction, indicating the partial degradation of cellulose, xylan and arabinan during the process [21]. As far as protein is concerned, the liquefaction and subsequent fermentation of starch results in an approximate 2.5 to 3-fold increase in the DDGS protein content, taking also into account the contribution of yeast, which is estimated to be around $20 \%$ [20]. However, over half of DDGS protein may become insoluble during the dry-grind ethanol process [22, 23]. In terms of amino acids, these are concentrated in the WGD fraction and the addition of CDS prior to the drying process is reported to slightly decrease the overall amino acid content in DDGS [2]. Yeast protein demonstrates a better amino acid profile, particularly with regards to limiting amino acids such as lysine, and its presence influences the amino acid profile of downstream products $[13,20]$.

\section{Treatment strategies for DDGS}

Several studies have reported the use of various treatment steps in order to extract and further process macromolecules contained in DDGS. As mentioned above, DDGS is characterized by a complex structure, consisting of hemicellulose, cellulose and proteins; therefore, an optimum combination of different treatment steps is often necessary for the efficient fractionation of its components. Due to the absence of a rigid lignocellulosic structure, DDGS is amenable to relatively mild processing that can lead to the production of several value-added streams, which can act either as end-products or starting materials for secondary processing; the types of valueadded products that can be derived from DDGS are discussed in section 4. The processing steps may include physical treatments to improve the material texture, chemical processes for the fractionation of compounds of interest and subsequent extraction and purification, enzyme- 
assisted processes, or a combination of these. The efficiency of such treatment steps on DDGS valorisation is summarised and discussed in the following sub-sections.

\subsection{Physical treatments}

DDGS samples can show significant variation in terms of their particle size distribution, ranging from 0.11 to $3.66 \mathrm{~mm}$, a fact that reflects the highly heterogeneous distribution of nutrients among the different size fractions [24]. The reduction of particle size by mechanical stress is often the first pre-treatment step of the solid starting materials, in order to facilitate subsequent chemical or enzymatic hydrolysis. Generally, small particles up to $0.40 \mathrm{~mm}$ are preferred for the efficient enzymatic hydrolysis of the solid materials [25], due their higher specific surface area, while for compounds such as cellulose, reductions in both the degree of polymerisation (DP) and crystallinity can be achieved this way [26]. Moreover, the particle size distribution is associated with the chemical and physical characteristics of DDGS and related materials, affecting aspects of the handling systems used, the processing facilities, as well as the digestibility and nutrient availability of DDGS feed [27]. Apart from this, a minimal particle size reduction is needed in most pre-treatment strategies, in order to overcome mass and heat transport issues.

In addition, the particle size distribution could determine the initial steps required for the fractionation of DDGS, aiming to generate compositionally enriched fractions. Based on this, the combination of sieving and air classification (also known as the Elusieve process), has been shown to effectively separate fibre from DDGS [28, 29]. Pilot scale experiments on maize DDGS samples demonstrated that through this approach, DDGS is separated into fibre and an enhanced fraction with lower fibre and $4.8 \%$ more protein than the initial material, which can be potentially more suitable for non-ruminant animals [29]. The Elusieve process is a simple, non-intrusive method that can be operated at the end of the dry-mill process with a capital investment estimation 
219 However, the highest revenue potential can be acquired only by the protein-enriched DDGS

220 fraction, whereas the conversion of the low fibre fraction to ethanol is not currently economically

221 feasible and therefore its exploitation will only be profitable if the fibre market value is high [28, 222 29].

\subsection{Chemical and physicochemical treatments}

225 A number of chemical treatment strategies have been studied for their efficiency for the 226 fractionation or degradation of the structural components of DDGS. These include either the use 227 of concentrated and diluted acid and alkali, or a combination of chemical and physical processing, 228 as in the case of ammonia fibre explosion (AFEX) and liquid hot water treatment. Depending on 229 the treatment of the raw material, however, different types of components might be formed that 230 can act as inhibitors and hinder subsequent processing, such as enzymatic hydrolysis or 231 fermentation. These inhibitors are degradation products and include organic acids (mainly acetic, 232 levulinic and formic acid), furan aldehydes, such as furfural deriving from xylose and 5233 (hydroxymethyl)-furfural (5-HMF) deriving from glucose, as well as phenolic acids and aromatic 234 compounds formed from lignin [30]. Therefore, the effectiveness of the chosen chemical pre235 treatment is determined by criteria such as high conversion yields, minimum formation of toxic 236 degradation products, efficient waste treatment and minimum energy input [31]. A summary of 237 the chemical treatments applied for DDGS and related by-products is given in Table 2.

$239 \quad 3.2 .1$ Ammonia fibre expansion (AFEX)

240 Ammonia fibre expansion (AFEX) technology possesses the advantage of combining physical 241 (high pressure and temperature conditions) and chemical (ammonia) processes for the efficient 242 pre-treatment of lignocellulosic materials. The incorporation of AFEX as a pre-treatment step 
243 leads to biomass swelling and consequently increases the accessible surface area, while supporting 244 cellulose decrystallisation. A minor part of hemicellulose is solubilised into its respective 245 monomers, whereas the lignin structure is rigorously altered and thus rendered more susceptible to 246 digestion [26, 32]. In the case of DDGS, AFEX can be performed under relatively mild conditions 247 (temperatures below $90^{\circ} \mathrm{C}$ and pressure range between $200-400 \mathrm{psi}$ ), due to the low lignin content, with the aim to increase subsequent enzymatic digestibility targeting monosaccharide production $249[33,34,35]$. Bals et al. [33] evaluated the efficacy of AFEX pre-treatment on the enzymatic hydrolysis of maize DDGS and reported AFEX conditions of $70^{\circ} \mathrm{C}$ and $0.8: 1 \mathrm{~kg} / \mathrm{kg}$ ammonia 251 loading as optimal for subsequent enzymatic hydrolysis of the pre-treated DDGS samples. AFEX 252 is an advantageous method for DDGS treatment due to the low lignin content, whereas moderate operation conditions and short residence times minimise the formation of microbial inhibitors 254 such as furfural and 5-hydroxylmethylfurfural (5-HMF). Moreover, the potential of ammonia recovery and recycling minimises chemical usage, and carrying out the process as a continuous operation is a viable option. On the other hand, application of AFEX on a large scale is still influenced considerably by the cost of ammonia, as well as by environmental concerns related to its unpleasant odour [26]. Additionally, AFEX treatment does not convert xylan into xylose monomers. In the case of DDGS, xylan represents around $35-40 \%$ of the total carbohydrate content; thus, the combination of AFEX treatment with hemicellulosic enzymes would be necessary in order to convert all the available DDGS carbohydrates into fermentable monosaccharides.

\subsubsection{Liquid hot water (LHW)/ Autohydrolysis}

265 Liquid hot water falls into the category of hydrothermal treatments, applied in order to solubilise 266 hemicelluloses and disrupt the cellulose and cell wall structure. These processes are also known as 267 autohydrolysis, hot compressed water (HCW) or hydrothermolysis. The autohydrolysis mode of 
action lies on the weakening of $\mathrm{H}$-bonding during exposure of materials to water at high temperatures $\left(150-240^{\circ} \mathrm{C}\right)$. Water is auto-ionised into acidic hydronium ions $\left(\mathrm{H}_{3} \mathrm{O}^{+}\right)$that act as catalysts on the glycosidic bonds. Additionally, hydronium ions are formed from the cleavage of O-acetyl groups and uronic acid substitution on arabinoxylan (glucuronoarabinoxylan), which further enable the catalysis of hemicellulose into oligosaccharides or monomeric sugars [36]. However, the latter mechanism can cause further degradation of monosaccharides into aldehydes (furfural from pentoses and 5-hydroxymethyl furfural from hexoses) that can hinder subsequent microbial fermentation. The formation of inhibitors can be reduced by controlling the $\mathrm{pH}$ in the range of 4-7 during the process. This type of pre-treatment produces mainly oligosaccharides [37, 38]. Moreover, since cellulose and lignin are hardly modified, they are amenable for recovery and further processing [39]. Recently, Samala et al. [40] studied the effect of autohydrolysis on maize DDGS fibre, separated using the Elusieve method. Under optimum conditions $\left(180^{\circ} \mathrm{C}, 20 \mathrm{~min}\right)$, $54.6 \%$ of the initial xylan content was hydrolysed to xylooligoasaccharides (XOS) (reported DPs up to 6), followed by traces of degradation products. The application of LHW on maize fibre has shown to yield $80 \%$ of soluble oligosaccharides and $20 \%$ of monosaccharides, while less than $1 \%$ of the initial carbohydrate content is lost due to the formation of degradation products [41]. DDGS pre-treatment with LHW has been reported to significantly increase the rate of the enzymatic hydrolysis of the samples post-treatment, leading to the generation of monosaccharide-rich streams, with glucose hydrolysis yields higher than $90 \%[34,35]$. LHW treatments attract interest due to the lack of a requirement for a catalyst and the low-corrosion potential. However, the process requires large volumes of water and high energy input. In the same manner as AFEX, LHW treatment requires subsequent enzymatic hydrolysis of the hemicellulosic content in the case of DDGS or related materials with high arabinoxylan presence.

\subsubsection{Dilute acid hydrolysis}


293 Dilute acid treatment has been extensively investigated as the means for enhancing biomass 294 digestibility through the breakage of rigid lignocellulosic structures. Hydrochloric, nitric and 295 sulphuric acids have been evaluated for biomass treatment, with the latter being the most common 296 acid of choice [36, 42, 43]. A disadvantage of this method is that depending on the hydrolysis 297 conditions, high levels of sugar degradation compounds such as furfural and 5-HMF, as well as 298 aromatic lignin degradation compounds can be formed. A number of studies have reported the 299 feasibility of using dilute sulphuric acid treatment for DDGS. For instance, Noureddini et al. [44] 300 performed a three-step acid pre-treatment followed by a single step enzymatic hydrolysis of maize 301 DDGS, yielding $128 \mathrm{~g} / \mathrm{L}$ of total monosaccharides (xylose and glucose monomers) that could 302 result in about 6.4 wt. \% ethanol. The effects of reaction temperature, time and acid concentration 303 on the yields of monomeric sugars, namely xylose, arabinose and glucose, have been primarily 304 investigated $[45,46,47]$. Low biomass concentrations $(5.0 \%-10.0 \%, \mathrm{w} / \mathrm{v})$ have been found to 305 favour hydrolysis of the hemicelluloses in DDGS samples, whereas increased acid concentrations 306 $(3.0 \%-4.0 \%, \mathrm{v} / \mathrm{v})$ decreased the duration of hydrolysis down to $30 \mathrm{~min}$. However, the temperature 307 of the treatment is critical since high temperatures (up to $140^{\circ} \mathrm{C}$ ) promote the formation of pentose 308 degradation products (furfural and furan resins) [45].

\subsubsection{Alkali pre-treatment}

Apart from the use of ammonia in AFEX technology as discussed above, bases such as sodium, potassium, calcium and ammonium hydroxide have been evaluated for biomass pre-treatment. In the presence of alkali, ester and glycosidic side chains are degraded whereas structural alteration of lignin and partial solubilisation of hemicellulose can occur [31] which provide the opportunity swelling of cellulose via the disruption of crosslinks between hemicelluloses and other components increases the porosity of biomass rendering it more accessible to enzymes [48]. 
318 Alkaline pre-treatments offer the advantage of low temperature operation compared to other 319 chemical treatments [49]. However, long residence time is needed followed by neutralisation of 320 the generated slurry in order to remove lignin and other inhibitors (phenolic acids, aldehydes, 321 furfural and salts) of enzymes. Moreover, alkaline treatment has been used on maize fibre for 322 hemicellulose extraction [50, 51], and more recently for DDGS, resulting in the isolation of a 323 hemicellulose-rich biopolymer [52]. Xu et al. [53] utilised a combination of alkali and xylanase 324 pre-treatment in order to extract cellulose from DDGS, achieving a crude cellulose yield of $7.2 \%$ $325(\mathrm{w} / \mathrm{w})$ with a cellulose content of $81 \%(\mathrm{w} / \mathrm{w})$. Recently, lime has been proposed for biomass pre326 treatment, offering the advantage of lower cost and less safety requirements compared to other 327 alkaline compounds [31]. Additionally, lime can be easily recovered from aqueous solutions as 328 insoluble calcium carbonate by reaction with $\mathrm{CO}_{2}[36]$.

\subsection{Biological treatments}

331 The application of enzymes is considered an efficient approach for the successful valorisation of 332 materials consisting of cellulose and hemicellulose. Enzymatic hydrolysis is often a secondary 333 treatment step and is required for the conversion of previously generated carbohydrate-rich 334 streams into their respective monomers. These can then be utilised as feedstock for the production 335 of chemicals through microbial fermentation and enzymatic or chemical synthesis reactions. 336 Aspects, such as the nature of the hemicellulose as well as the desired end-products of the 337 bioconversion define the choice of enzymes in this step.

339 The main enzymes used in hydrolysis of physically and/or chemically pre-treated DDGS are 340 hemicellulases and cellulases, often co-operating in a synergistic fashion for the degradation of 341 the hemicelluloses and cellulose present. A summary of the most frequently used enzymes 342 employed in hydrolysis of hemicellulosic materials is presented in Table 3. 
345 Cellulases are derived from microorganisms or plants; they constitute a mixture of several 346 enzymes and are responsible for hydrolyzing cellulose to soluble monosaccharides. Based on their 347 structural properties, three major types of cellulase activities can be distinguished: endo-1,4- $\beta$ 348 glucanases (EC 3.2.1.4), cellobiohydrolase (EC 3.2.1.176), exo-1,4- $\beta$-glucanases (EC 3.2.1.91) 349 and $\beta$-glucosidases (EC 3.2.1.21) [54,55]. Endo-glucanases cleave cellulose chains in low 350 crystallinity regions of the cellulose fibre and create free-chain ends that can be further attacked 351 by exo-glucanases, acting from the non-reducing end, or by cellobiohydrolases acting 352 progressively from the reducing end of cellulose both releasing cellobiose units. The latter are 353 hydrolysed by $\beta$-glucosidase to produce glucose. In lignocellulosic biomass, the lignin can block 354 the access of cellulases to cellulose; therefore, pre-treatment processes that separate lignin from 355 cellulose and the hemicellulose component can substantially increase hydrolysis rates [31]. 356 However, DDGS contains relatively low amounts of lignin 3-5\% (w/w) and therefore a 357 delignificationpre-treatment step is not required.

\subsubsection{Hemicellulases}

360 Hemicellulose is a heterogeneous mixture of polysaccharides and, as a consequence, a range of enzymes is needed in order to achieve effective hydrolysis. The major hemicellulose in cereal 362 grains is arabinoxylan and enzymes involved in its degradation can be divided into 363 depolymerising enzymes, which act on the xylan backbone, and accessory enzymes that remove 364 substituent groups [55]. The principal hydrolytic enzymes employed for xylan degradation to 365 monomers are endo-1,4- $\beta$-xylanase (EC 3.2.1.8), which attack the xylan backbone and yield short366 chain oligosaccharides, and $\beta$-xylosidase (EC 3.2.1.37), which cleave oligosaccharides into xylose 367 monomers. Moreover, the xylan backbone can be decorated with various substituents, such as 
arabinose and galactose, ferulate and acetate, so the action of ancillary enzymes is required to remove these substituent groups and facilitate backbone degradation [55]. To this end, $\alpha$ arabinofuranosidase (EC 3.2.1.55), feruloyl esterase (EC 3.1.1.73), $\alpha$-galactosidase (EC 3.2.1.22) acetyl xylan esterase (EC 3.1.1.72) and xylan $\alpha$-1,2-glucuronidase (EC 3.2.1.131) act synergistically with xylanases and xylosidases to achieve complete xylan hydrolysis [56].

\subsubsection{Enzymatic degradation of DDGS}

For the enzymatic hydrolysis of DDGS and related materials, the choice of enzymes is related to the desired end-product. A summary of enzyme combinations that have been employed for DDGS hydrolysis and their respective conversion yields is presented in Table 4. If the DDGS hydrolysate is intended to be utilized as a fermentation feedstock (e.g. for production of ethanol or platform chemicals), cellulose-degrading enzymes can be used for the release of the glucose monomers [57]. Cellulose conversion rates from untreated DDGS are reported to be relatively higher in the presence of cellulase and $\beta$-glucosidase enzyme mixtures, compared to other biomass by-products such as maize stover. Glucose yields of $76 \%$ were achieved after $72 \mathrm{~h}$ of hydrolysis of maize DDGS with low solid loadings $(5 \%, w / w)$ [35]. On the other hand, pre-treatment of DDGS is highly advantageous for nearly complete cellulose hydrolysis (98\%) within the same time [35]. WDG can be less susceptible to hydrolysis, showing lower yields by approximately $30 \%$ in high substrate loadings $(15 \%$, w/w). This can be overcome through the use of auxiliary enzymes (xylanases, ferulic acid esterases) that act on the hemicellulose structure during the course of hydrolysis, and as more sites become susceptible to cellulase attack, glucose yield is increased [35]. Additionally, compounds produced during the pre-treatment step, such as lignin-derived phenolics as well as xylan oligomers, can act as inhibitors of cellulases [58]. Due to the fact that cellulases have a minor impact on hemicellulose hydrolysis, further digestion with xylanase and ferulic acid esterase mixtures is required for the production of hemicellulose-derived pentosans 
393

[59]. However, Dien et al. [34] observed that additions of the above mentioned commercial enzymes did not favour the release of xylose and arabinose from pre-treated DDGS. On the contrary, cellulase blends with pectinase and ferulic acid esterase, increased the hemicellulose conversion yields. Although DDGS does not contain any pectin, commercial pectinases usually contain multiple side-activities and may contribute to achieving increased monosaccharide yields [34]. Banerjee et al. [60] reported that increased levels of mannanase were also needed in order to enhance the release of glucose from AFEX-treated DDGS. In addition to glycosyl hydrolases, proteolytic enzymes can be applied for the extraction of proteins from DDGS [22, 33], as the means for increasing arabinoxylan extraction [61].

The choice of the pre-treatment strategy for DDGS depends greatly on the aims of the biorefinery. On one hand, enzymatic hydrolysis is a less energy intensive process as opposed to chemical treatments, offering the advantage of selective catalysis of carbohydrates, generating monosaccharide-rich streams suitable for microbial conversion. However, enzymatic pretreatment is often hindered by substrate concentration, enzyme activity and end-product inhibition. To this end, the production of tailored multi-enzyme cocktails (containing optimised cellulase/hemicellulase proportions) with higher specific activities compared to current commercial enzymes, obtained through screening or protein engineering approaches, is expected to reduce capital costs associated with the pre-treatment step. Physico-chemical treatments such as steam explosion are considered cost-effective and have a realistic potential for industrial scale processing. They can offer high yields of monomeric sugars and enhanced hemicellulose hydrolysis. However, their combination with subsequent enzymatic processes is often problematic due to the formation of inhibitory compounds during the pre-treatment process (e.g. in the case of dilute acid hydrolysis) or to the requirement for additional steps prior to enzyme hydrolysis (e.g. neutralisation step in the case of alkaline treatment). Thus, it seems rather unlikely that a process 
aiming to fully exploit DDGS will rely on a single treatment step due to the complex structure of DDGS.

\section{Value-added products from DDGS}

The heterogeneous nature of DDGS allows its biotransformation into several added-value products. These can either be subjected to further purification leading to primary products, or used as starting materials for secondary processing, as part of a biorefinery strategy. A schematic representation of various added-value products from DDGS based on the biorefinery concept is given in Fig. 2. These include biofuels, biopolymers, platform chemicals, prebiotic oligosaccharides as well as packaging materials. All the above mentioned products could be derived by effectively exploiting two principal components that account for $65-70 \%$ of the total DDGS composition, i.e. carbohydrates and proteins, and have a variety of potential applications in industrial sectors such as food, chemicals and packaging. Currently, the bioethanol production process generates DDGS and $\mathrm{CO}_{2}$ as co-product streams, both of which have market values for the industry. Therefore, the choice of product(s) deriving from DDGS should be of higher added value in order to compensate for the additional energy and equipment costs. Ideally, the additional process should be easily incorporated into existing production processes. Moreover, a successful process should not be affected by feedstock variability, which could stem from the use of blended cereals as raw materials for bioethanol production. A biorefinery strategy could aim to use intermediate products of the DDGS biotransformation process as starting materials for the generation of added-value components. From an economic perspective, in the bioethanol production process, apart from feedstock price fluctuation, the thermal processing of the WDGCDS mixture is the most costly part of production [62]; however it is required in order to confer shelf-life stability during transportation of the DDGS used as animal feed. Taking this into account, WDG could be used as substrate for chemical/enzymatic treatments as it has been shown 
443 to contain higher amounts of total carbohydrate and protein (on a dry matter basis) compared to

444 DDGS [13]. Another in-process sample that can be utilised for the production of added-value

445

446

447

448

449

450

451

452

453

454

455

456

457

458

459

460

461

462

463

464

465

466

467

components is thin stillage (TS). TS contains a complex mixture of carbon sources, such as

soluble sugars, by-products of fermentation, such as glycerol and organic acids, and also yeast cells [13] that can serve as an ideal source of nutrients for microbial fermentations. A number of studies have demonstrated the feasibility of using TS directly as a fermentation feedstock or as source of liquid nutrients supplemented with additional carbon sources for the production of microbial metabolites such as lipids, solvents, organic acids and extracellular polysaccharides (Table 5). An additional advantage reported in these studies is the potential remediation of TS through the reduction of their total solids and chemical oxygen demand (COD) [63, 64].

\subsection{Biofuels, platform chemicals and biopolymers}

One of the most studied biotechnological processes for DDGS upgrade is bioethanol production, as the means for generating additional profit to bioethanol plants, through the microbial conversion of non-starch carbohydrates. Initial studies aimed to produce a cellulose-derived glucose-rich stream from DDGS which can be fermented by hexose-consuming wild-type microbial strains that exhibit high ethanol tolerance, such as Saccharomyces cerevisiae and Zymomonas mobilis. However, genetic engineering has since allowed the development of modified strains capable of fermenting pentoses (i.e. xylose and arabinose) by introducing pentose-metabolizing pathways from bacterial strains of $E$. coli or natural xylose-fermenting yeasts such as Pichia stipitis and Candida shehatae to S. cerevisiae strains [65]. More recently, the concept of consolidated bioprocessing (CBP) has emerged, aiming to reduce the cost of added enzymes in the pre-treatment step. In CBP, lignocellulosic materials can be directly fermented into the desired products in a single step by microorganisms performing simultaneous saccharification and fermentation of the substrate [66, 67]. CBP benefits from the elimination of 
the enzyme production process, since engineered yeast strains capable of secreting hydrolytic enzymes, such as cellulases, can be used. However, in some cases, high density cultures (100 g/L wet cell weight) are required for the effective hydrolysis of the raw materials [68]. A major obstacle in the process is the difference in the optimum temperatures between saccharification and fermentation [69]. To this end, research on the construction of thermotolerant recombinant yeast strains is ongoing [70]. Apart from DDGS, complementary ethanol production can be achieved through the direct fermentation of TS. A metabolically engineered Escherichia coli strain was capable of ethanol production, by utilizing simultaneously glycerol and the sugars present in TS media, after supplementation with mineral salts [71].

Typically, DDGS contains around 14-18\% of cellulose. Based on literature data, the combination of AFEX treatment and subsequent enzymatic hydrolysis can convert up to $93 \%$ of cellulose to fermentable glucose. If the hemicellulose content (accounting for around 25-28\% of total DDGS composition) is further hydrolysed, an overall yield of $92 \%$ of total hemicellulose and cellulose conversion into fermentable hexoses and pentoses can be achieved (Fig 2). In the ideal scenario of a complete fermentation of the available sugars and the absence of inhibitory parameters, the process may contribute up to $15 \%$ more ethanol than the conventional dry-grind process, whereas the generated DDGS in such a process would be enriched with protein (30-40\% of total mass, compared to $\sim 30 \%$ in standard DDGS) and could be marketed as a livestock feed at a higher price than its current price, especially if it provides the amino acid requirements for animal feeds, in terms of lysine content [72]. Kim et al. [72] investigated three case studies of process alternatives based on recycling the pre-treated and hydrolysed distillers' grains, and assessed their effect on the overall ethanol yields. They concluded that a $14 \%$ ethanol yield increase could be achieved by releasing the additional fermentable sugars present in distiller's grains by further processing and hydrolysis of fermentable glucans [72]. However, the cost of cellulosic ethanol is still high 
493 (estimated typically around $£ 0.6$ per litre) [73]. It has been proposed that the combination of 494 reduced enzyme costs and the higher market price of DDGS enriched in protein could render the 495 'DDGS to bioethanol' process a viable prospect for the biofuel industry [74].

497 Another approach towards the production of added-value compounds is the microbial 498 transformation of DDGS hydrolysates into platform chemicals, such as succinic acid. The latter 499 can be used as a precursor for a variety of chemical compounds that have a number of applications 500 in the food, pharmaceutical, and plastic industries [75]. The potential of replacing a petroleum501 based chemical process with a bio-based process for succinic acid production attracts much 502 research interest recently. The current market price of succinic acid is estimated as around $£ 4,000$ 5036,000 per tonne, depending on its purity [76]. Microbial production of succinic acid by strains of 504 Anaerobiospirillum succiniciproducens can be achieved at conversion yields as high as $91 \%$ (on 505 glucose-based substrates) [77]. Based on the same scenario, which includes the conversion of 506 cellulose to glucose, around $19 \%$ of the initial DDGS amount could be converted into succinic 507 acid, taking into account an optimum bioconversion yield of 91\% (Fig 2). DDGS bioconversion to 508 succinic acid could be further enhanced, since most of succinic acid-producing strains 509 (Actinobacillus succinogenes, Mannheimia succiniciproducens) are capable of utilising pentose 510 sugars as carbon substrates with satisfactory conversion yields $(55-80 \%)$ [78, 79].

512 An additional promising bioconversion route of DDGS hydrolysates includes the microbial 513 production of biodegradable biopolymers, such as polyhydroxyalkanoates (PHAs). The 514 biodegradable plastics industry is currently growing fast, with world production reaching nearly 515740,000 tonnes in 2013, while projections estimate that the total production volume will reach 516 approximately 2.96 million tonnes by 2021 [80]. PHAs are polyesters that contain hydroxyl517 alkanoic acids as monomers and exhibit resistance against high temperatures (up to $180^{\circ} \mathrm{C}$ ) as 
well as oxygen barrier properties. Among the PHAs, polyhydroxybutyrate (PHB) is the most common biopolymer with a wide spectrum of applications. PHAs are synthesized intracellularly by a number of bacterial strains such as Cupriavidus necator, Bacillus sp., Pseudomonas sp. or Aeromonas sp. [81]. PHAs market price is still much higher than those of other bio-based polyesters (approx. $£ 7-9 / \mathrm{kg}$ ), [80] whereas around 50\% of the total PHAs cost is due to the substrate cost [82]. The use of low-value feedstocks derived from waste streams in combination with an environmentally friendly and cost effective extraction step, could potentially lead to the establishment of a competitive PHA production process based on DDGS.

Based on the applied pre-treatments, DDGS hydrolysates can contain a mixture of glucose, xylose and arabinose as carbon sources for microbial conversions. A number of PHA-producing strains have been reported to catabolise xylose, the majority of which however demonstrate low specific PHA rates and production yields $[83,84]$ compared to those achieved in glucose or sucrose-based media $[85,86]$. Taking a best case scenario based on literature data showing a $38 \%$ of DDGS cellulose-derived glucose after AFEX treatment [34], approximately $8 \mathrm{~kg}$ of PHB per $100 \mathrm{~kg}$ of DDGS can be potentially achieved (calculations based on glucose conversion data from Ryu et al. [87]).

Poly-lactic acid (PLA), originating from lactic acid polymerisation, represents another important polymer in the field of biodegradable materials. PLA has unique biodegradability and biocompatibility properties, with potential applications in packaging and agricultural products, as well as in medical and textile industries [88]. In 2013, about 143,200 tonnes of PLA were produced worldwide; the total PLA market volume for 2021 is forecasted to rise to approximately 465,500 tonnes with a rise in demand of around $16 \%$, and its current price is around $£ 2-4 / \mathrm{kg}[80]$. Europe is the third largest market after North America and Asia-Pacific [80]. The building 
monomer for PLA, lactic acid, occurs in two optical isomers, L- and D-lactic acid, which can be 544 obtained via chemical synthesis (hydrolysis of lactonitrile) or through microbial fermentation. In 545 the latter case, the enzymatic capacity of bacterial strains (Lactobacillus spp.) determines the 546 stereo specificity of the lactic acid produced. For this reason, obtaining optically pure lactic acid is 547 of great importance [89]. As is the case for most microbial conversions, the operation and 548 purification costs are also of primary importance. In lactic acid bacteria (LAB), hexose catabolism 549 is usually performed via the homofermentative pathway, producing solely lactic acid. On the other 550 hand, most LAB catabolise pentoses via the heterofermentative pathway, generating by-products 551 such as acetic acid and ethanol. This causes a decrease in lactic acid yield. Although a number of 552 novel lactic acid-producing strains have been reported to efficiently ferment xylose to lactic acid 553 with high yields and optical purity (95\% and 99.6\%, respectively) [90], the microorganism of 554 choice should be capable of utilising simultaneously the mixed sugars present in the 555 hemicellulosic hydrolysates. Recently, Tsuge et al. [91] reported the homofermentative D-lactic 556 acid production by an engineered $L$. plantarum strain capable of simultaneously catabolising 557 xylose and glucose in a two-step production system, based on the sequential cultivations of 558 growing and resting cells. Lactic acid production yields were higher than $90 \%(\mathrm{w} / \mathrm{w})$. In such a 559 case, the fermentation of the mixed sugars contained in a DDGS hydrolysate could potentially 560 lead to approximately $28 \mathrm{~kg}$ of lactic acid per $100 \mathrm{~kg}$ of DDGS.

4.2 Xylan and xylo-oligosacchrides

563 Xylan constitutes part of the hemicellulosic fraction and represents the major polysaccharide in 564 bioethanol DDGS, accounting for approximately $35-40 \%$ of the total carbohydrates (Kim et al. 565 2008a). In the wheat grain cell, the xylan consists of a linear backbone of D-xylopyranosyl units, 566 which may be mono-substituted with $a$-L-arabinofuranosyl residues on position O-3 ( 21\%) or di567 substituted on positions O-2 and O-3 ( 13\%) [92, 93]. Glucuronic acid or its 4-methyl ether 
derivative can also be linked in the O-2 position of xylopyranosyl residues. Arabinofuranosyl residues linked on position $\mathrm{O}-3$ of the xylose units may be ester-linked to ferulic acid, which may undergo oxidative dimerization to form covalent cross-linkages between the xylan chains [93]. These cross-links, in addition to the interactions of arabinoxylans (AX) with other cell wall components such as cellulose and lignin, are responsible for the water-insoluble nature of a high proportion of wheat grain arabinoxylan. In wheat flour, water-soluble AX account for $25 \%$ of the total AX content, but the proportion is much lower in bran and whole grain [94]. The structure and chemical properties of soluble and insoluble AX in the wheat grain have been intensively studied, however for DDGS limited information is available. Most studies on DDGS exploitation are focused on the solubilisation of the insoluble AX fraction, while hardly any information is available on the effect of the DDGS production process on the solubility of AX. In a recent study [18] comparing the composition of maize grain to that of maize DDGS, an increase in the soluble AX content in DDGS compared to grain was observed, which suggests that the non-starch polysaccharide fraction is modified during the fermentation process and the subsequent drying process. This can be attributed to factors such as the presence of exogenous or yeast -derived fibre degrading enzymes, as well as to the mechanical and heat treatments during DDGS production [18].

Apart from xylan hydrolysis to its respective monomers, an alternative way for the efficient valorisation of DDGS xylan is its conversion to xylo-oligosaccharides (XOS) or arabinoxylooligosaccharides (AXOS), compounds that exert potential prebiotic health effects. According to Gibson et al. [95], "prebiotics are selectively fermented ingredients that allow specific changes, both in the composition and/or activity in the gastrointestinal microflora that confers benefits". Prebiotics stimulate the population of beneficiary bacteria (e.g. Bifidobacterium spp. and Lactobacillus spp.) leading to the production of short-chained fatty acids (SCFAs), mainly acetate, 
593 propionate and butyrate. SCFAs are used as energy source by colonic epithelial cells and may 594 function as primary protective agents against colonic disorders, inhibit the growth of pathogenic 595 microorganisms, while they also have immunomodulatory properties. The main commercial 596 prebiotics include fructo-oligosaccharides (FOS), inulin-type fructans and galacto597 oligosaccharides (GOS). In the case of XOS (mainly mixtures of DP2 and DP3 are produced 598 commercially) and the AXOS prebiotic effects have been shown primarily in vitro, whereas data 599 from human studies are limited although a study has been recently published [96].

600

A small number of studies have exploited the isolation of insoluble xylan from cereal- based by602 products, such as maize fibre or maize cobs. Different methods have been assessed for their 603 efficiency towards xylan extraction, including chemical (alkaline, acid, bleach, organic solvents), 604 enzymatic (xylanases) and mechanical assisted treatments (extrusion, hydrothermal, ultrasound 605 and microwave) [97]. DDGS is an advantageous starting material for xylan extraction as it 606 contains low amounts of lignin (3-5\%), therefore a delignification step is not needed. Yields of up to $\sim 25 \%$ were obtained from DDGS in a process consisting of alkaline extraction and ethanol 608 precipitation [53].

DDGS xylan has been previously evaluated as an additive for the preparation of gluten-based biodegradable films [98]. The water vapour transfer rate of the films was not affected by xylan addition, whereas the production conditions and xylan origin influenced their mechanical and solubility properties. More recently, the feasibility of producing films from hemicellulose-rich 614 fractions of DDGS was evaluated [53]. The extracted fraction contained around 52\% 615 hemicelluloses (mainly arabinoxylan) and 18\% protein. The films produced from this fraction 616 were stiff and had a high glass transition temperature, as a result of a greater degree of 617 polymerisation in DDGS arabinoxylans, and due to the presence of impurities in the extracted 
619 increased considerably the paper tensile strength. Although a promising application has been identified, optimisation of the extraction procedure is needed in order to increase the purity of the extracted xylan, decrease the environmental impact of the extraction process and eliminate the presence of impurities, such as proteins and crude fat. Finally, it is worth mentioning that a xylanbased packaging material is currently marketed by Xylophane under the commercial name Skalax ${ }^{\circledR}$. Specifically, cereal hulls and husks are used as starting materials and the extracted material is used as paper coating, acting as a migration barrier.

\subsection{Protein}

DDGS contains substantial amounts of protein $(\sim 30-35 \%, w / w)$, that justifies its application as a dietary supplement in livestock feed. Wheat proteins comprise gluten storage proteins, which account for about $80 \%$ of the total grain protein, and a heterogeneous range of non-gluten proteins ( 20\%). The non-gluten proteins comprise structural and metabolic components as well as storage components, and include abundant water-soluble (albumin) components of mass below about $25 \mathrm{kDa}$ [99]. By contrast, gluten proteins are not soluble in water and are classically divided into monomeric gliadins and polymeric glutenins. Both groups are defined as prolamins as they are soluble in alcohol-water mixtures, either as native monomers (gliadins) or after reduction of the inter-chain disulphide bonds (glutenin subunits) [100, 101]. Based on their genetics, structure and 637 evolution, wheat prolamins can be categorised in three major groups: sulphur-rich (S-poor) 638 prolamins which correspond to $\omega$-gliadin monomers, sulphur-poor (S-rich) prolamins 639 corresponding to of $\alpha$ - and $\gamma$-gliadins monomers and low molecular weight subunits of glutenin in 640 wheat, and high molecular weight (HMW) prolamins corresponding to high molecular weight 641 subunits [101]. The maize prolamins, known as zein, account for almost $80 \%$ of the total grain 
protein. $a$-Zeins are the major prolamin group occurring as monomers or oligomers, whereas minor zien groups $(\beta-, \gamma$ - and $\delta$-zeins) occur as polymers [101].

Praire Gold Inc. developed a process named COPE (Corn Oil and Protein Extraction) for the extraction of zein and oil from maize DDGS; this was achieved by fractionation at the front-end of the dry-grind ethanol process. Through this technology, several grades of high quality zein fractions are produced, containing varying amounts of xanthophylls. However, zein yields are low $(2-5 \%, w / w)$ and high amounts of solvents are required in the process. On the other hand, a backend process for protein extraction is more attractive since DDGS contains high amounts of protein as a result of starch removal and mass reduction [102]. Nevertheless, a commercial back-end extraction of proteins from DDGS protein has not been applied.

Several different approaches have been proposed for DDGS protein extraction, including aqueous ethanol, alkaline-ethanol and enzyme treatments. Bandara et al. [103] investigated the efficiency of protein extraction from triticale DDGS and concluded that treatment with alkaline ethanol gave maximum protein purity of $66 \%(\mathrm{w} / \mathrm{w})$; however, extraction yields were limited to $21-30 \%(\mathrm{w} / \mathrm{w})$. For corn DDGS, higher purities of extracted protein have been reported (90\% w/w) accompanied by average extraction yields of $44 \%(\mathrm{w} / \mathrm{w})$ using aqueous ethanol extraction in the presence of reducing agents [104]. The purity and yield of the extracted proteins from DDGS still remains a challenge, since an ideal method should provide high protein purity without compromising extraction yields. DDGS proteins often show low extractability, possibly due to the heating process that is applied and can cause denaturation of the proteins and changes in their properties [103]. During the final stage of the dry-grind ethanol production process (Fig. 1), the WDG and CDS mixture is subjected to intense thermal treatment. The extent of heating varies between plants for DDGS production but can reach up to $200^{\circ} \mathrm{C}$. It is possible that the utilisation of in- 
667

668

669

670

671

672

673

674

675

676

677

678

679

680

681

682

683

684

685

686

687

688

689

690

691

process samples, such as whole stillage or WDG, could lead to the extraction of proteins with

higher yields and purity, since up to that point of the process, mild heating steps are applied during the liquefaction of biomass $\left(\sim 50^{\circ} \mathrm{C}\right)$ and the distillation of ethanol $\left(\sim 80^{\circ} \mathrm{C}\right)$. Looking towards the commercialisation of a large-scale protein extraction process from DDGS, environmental aspects should also be taken into account, with respect to solvent selection and extraction method, as well as energy usage.

DDGS protein can be exploited in a variety of medium-value industrial applications, such as for the production of biodegradable films, coatings and biodegradable plastics, which can be used in food and agricultural applications $[105,106]$. In particular, wheat gluten has been extensively researched as a natural starting material for the development of biodegradable films, due to its remarkable cohesive and elastic properties, as well as its susceptibility to chemical modifications $[107,108]$. For the production of protein-based films, plasticisers are usually added in levels of $15-40 \%$ of protein weight and contribute to the improvement in the flexibility and extensibility properties of films. Low molecular size components of low volatility, such as sorbitol, xylitol, glycerol, mannitol, diglycerol and polyvinyl alcohol, have been tested as plasticisers for wheat gluten films [109]. Among those, glycerol has many advantages as it is non-toxic and suitable for use in the food industry. Wheat gluten-based films are water-insoluble and present properties similar to those of zein films [110]. They possess higher water vapour permeability but their mechanical properties are inferior compared to most synthetic films [111]. By contrast, starchbased films are used primarily in food packaging, and possess excellent oxygen-barrier properties but poor mechanical properties. Moreover, cellulose-based films hold their share of the market, producing tough, flexible and transparent films, resistant to fats and oils and sensitive to water. Gluten-based films possess better mechanical and gas barrier properties compared to polysaccharide films, while their mechanical stability can be improved by the incorporation of 
692

693

694 695 696 697 698 699 700 701 702 703 704 705 706 707 708 709 710 711

plasticisers [112]. The commercial production of gluten-based films is yet to be established, whereas starch-based biodegradable products hold a major share, with a market volume of 162,500 tonnes in 2013 [80]. Attempts have been made to modify the structure and improve the functionality of gluten for films using a variety of methods, including incorporation of hydrophobic compounds [113], enzymatic cross-linking [114], controlled thermal treatment [115] and gamma-irradiation [116]. Further research is needed in order to develop processes and products that can be applied on a commercial scale and compete in terms of price and functionality with petroleum-derived polymers.

\subsection{Phenolic acids}

DDGS is a potential source of phytochemicals and in particular phenolic compounds, including ferulic, sinapic, $p$-coumaric, caffeic and vanillic acids. Among these, ferulic and $p$-coumaric account for $80 \%$ of the total phenolics [117]. Luthria et al. [118] reported a total phenolic acid concentration of $5.99 \mathrm{mg} / \mathrm{g}$ for DDGS, consisting of $4.59 \mathrm{mg} / \mathrm{g}$ ferulic acid and $0.72 \mathrm{mg} / \mathrm{g} p$ coumaric acid. Additionally, it has been demonstrated that the phenolic content of DDGS is enhanced approximately 3-fold (in dry basis) compared to the starting material before fermentation as a result of starch depletion [119], whereas the effect of the dry mill processing on phenolic acid content is minimal [120]. Due to their unique physiological properties, phenolic acids have been proposed to have numerous health benefits due to their radical scavenging ability, inhibition of lipid peroxidation and protection against LDL oxidation in the human body [121]. For this reason, they could be marketed as nutraceuticals, and more specifically as natural sources of antioxidants in foods and dietary supplements [122]. Moreover, ferulic acid can be used for the commercial production of bio-vanillin, an aromatic flavour compound used by the food, pharmaceutical and cosmetics industries, via microbiological conversion routes [123,124]. 
717 Ferulic acid is predominantly bound on the cell wall AX components, with dimeric forms 718 accounting for between 4.2 and $8.6 \%$ in wheat cultivars [125]. An enzymatic hydrolysis process 719 utilising feruloyl esterases, in synergy with main-chain degrading enzymes such as endo720 xylanases and pectinases, can lead to the extraction of ferulic acid and its respective dimers $721[126,127]$. The combination of xylanase and ferulic acid esterase has been reported to release up 722 to $86 \%(\mathrm{w} / \mathrm{w})$ of the total ferulic acid in wheat aleurone [128]. In the case of DDGS, solvent723 assisted methods, such as aqueous ethanol, or ultrasound pre-treatments, have been studied for the 724 extraction of phenolic acids from DDGS. Ultrasound pre-treatment of DDGS was reported to 725 increase the extraction yield of phenolic compounds by $14.9 \%$, as opposed to non-treated DDGS 726 [129] Additionally, the application of microwave irradiation in 50\% aqueous ethanol solutions of 727 DDGS led to the production of extracts with $12 \mathrm{mg} / \mathrm{g}$ of phenolic content [117]. So far, lab-scale 728 studies have indicated the potential of producing phenolic-rich extracts from DDGS. Future work 729 is needed in order to evaluate the scalability of the technologies and assess the economic 730 implications of such processes.

4.5 Oil and Biodiesel

733 Typically, DDGS contains around 10-12\% (w/w) of oil. The fatty acid composition of DDGS oil 734 resembles that of the starting grain (usually maize or wheat), being rich in linoleic acid ( $\sim 55 \%$, 735 w/w), while it also contains substantial amounts of oleic $(\sim 28 \%$, w/w) and palmitic acid $(\sim 16 \%)$ 736 [130]. Extracting oil from DDGS creates an additional profit to bioethanol plants as the crude 737 maize oil price was estimated at around $£ 500$ per ton in 2013 . The extracted oil is marketed either 738 for biodiesel production or as refined maize oil. Oil removal leads to the production of DDGS 739 with a higher protein content, a valuable feed component which due to its low residual oil content 740 (5-9\%, w/w compared to 10-14\% in DDGS) can be marketed for non-ruminant diets (e.g. 741 swine). Currently in the US, more than $50 \%$ of maize-based bioethanol plants are extracting oil, 
743 feed-fats, mainly by the poultry industry.

744

745 Maize oil is either extracted from the germ of the grain prior to fermentation via a 746 solvent/pressing-assisted process, or post-fermentation from the whole or thin stillage (back-end 747 extraction process). In the latter case, oil is extracted by a series of centrifugation, heating and 748 condensation steps, yielding 60-75\% of the total oil content. Moreover, DDGS extracted oils were 749 found to contain increased amounts of tocotrienols and carotenoids (1762 and $75 \mu \mathrm{g} / \mathrm{g}$, 750 respectively) compared to maize germ oil (235 and $1.3 \mu \mathrm{g} / \mathrm{g}$, respectively); this offers the 751 advantage of increased stability for crude maize oil as opposed to maize germ oil due to the 752 antioxidant activity of the above compounds [130]. In the case of a DDGS biorefinery, the 753 formation of glycerol as a by-product of the biodiesel process could be potentially used as a 754 plasticiser for the production of biodegradable films from DDGS proteins (Fig. 2).

\section{Conclusions}

DDGS constitutes a by-product with potential for transformation into numerous added-value products. Due to its heterogeneous nature several pre-treatment steps have been proposed targeting specific compounds of interest as primary products or starting materials for subsequent bioconversion processes. The parent grains as well as the processing systems have been shown to significantly influence the physical and chemical characteristics of DDGS, and consequently the availability and extractability and of its components. The development of a commercially viable process scheme for the valorisation of DDGS within the biorefinery concept requires the production of medium to high added-value compounds in order to counterbalance capital investment and operating costs. Research thus far has demonstrated that this is feasible at the 
766 laboratory and in some cases pilot scale although more industrial research coupled with detailed 767 process economics are needed before leading to commercial realisation and exploitation.

\section{Acknowledgements}

770 The authors would like to acknowledge the Integrated Biorefining Research and Technology Club 771 (IBTI) of the UK Biotechnology and Biological Sciences Research Council (BBSRC) for their 772 financial support on a collaborative research project entitled "Development of a process scheme 773 for the production of high value functional products from DDGS" (BB/J019429/1-University of 774 Reading; BB/J019380/1 - Rothamsted Research). This work is also included in the Cost Action 775 TD1203 entitled "Food waste valorisation for sustainable chemicals, materials \& fuels (EUBis)". 


\section{References}

778

779

[1] OECD-FAO. OECD-FAO Agricultural Outlook 2011-2020. 2011, OECD Publishing.

[2] Kingsly ARP, Ileleji KE, Clementson CL, Garcia A, Maier DE, Stroshine RL, Radcliff S. The effect of process variables during drying on the physical and chemical characteristics of corn dried distillers grains with soluble (DDGS)-Plant scale experiments. Bioresour Technol 2010; 101: 193-199.

[3] OECD-FAO. OECD-FAO Agricultural Outlook 2009-2018 2009, OECD Publishing.

[4] Klopfenstein TJ, Erickson GE, Bremer VR. Use of distillers by-products in the beef cattle feeding industry. J Anim Sci 2008; 86: 1223-1231.

[5] Schingoethe DJ, Kalscheur KF, Hippen AR, Garcia AD. Invited review: The use of distillers products in dairy cattle diets. J Dairy Sci 2009; 92:5802-5813.

[6] Anonymous. Animal Feed Statistics for Great Britain - March 2015. Department for Environment Food and Rural Affairs 2015:1-13.

[7] Directive 2009/28/EC of the European Parliament and of the Council on the promotion of the use of energy from renewable sources and amending and subsequently repealing Directives 2001/77/EC and 2003/30/EC. 2009, OJ L140/16.

[8] Belyea RL, Rausch KD, Clevenger TE, Singh V, Johnston DB, Tumbleson ME. Sources of variation in composition of DDGS. Anim Feed Sci Techn 2010; 159: 122-130.

[9] Tedeschi LO, Kononoff PJ. Karges K, Gibson ML. Effects of chemical composition variation on the dynamics of ruminal fermentation and biological value of corn milling. J Dairy Sci 2009; 92: 401-413.

[10] Belyea RL, Rausch KD, Tumbleson ME. Composition of corn and distillers dried grains with soluble from dry grind ethanol processing. Bioresour Technol 2004; 94: 293-298.

[11] Batal AB, Dale NM. True metabolisable energy and amino acid digestibility of distillers dried grains with solubles. J Appl Poultry Research 2006; 15:89-93. 
[12] Ortin WGN, Yu P. Nutrient variation and availability of wheat DDGS, corn DDGS and blend DDGS from bioethanol plants. J Sci Food Agric 2009; 89:1754-1761.

[13] Liu K. Chemical composition of distillers grains, a review. J Agric Food Chem 2011; 59:1508-1526.

[14] Cromwell GL, Herkelman KL, Stahly TS. Physical, chemical and nutritional characteristics of distillers dried grains with soluble for chicks and pigs. J Anim Sci 1993; 71: 679-686.

[15] Kim Y, Mosier NS, Hendrickson R, Ezeji T, Blaschek H, Dien B, Cotta M, Dale B, Ladisch MR. Composition of corn dry-grind ethanol by-products: DDGS, wet cake and thin stillage. Bioresour Technol 2008; 99: 5165-5176.

[16] Spiehs MJ, Whitney MH, Shurson GC. Nutritional database for distiller's dried grains with soluble produced from new ethanol plants in Minnesota and South Dakota. J Anim Sci 2002; 80: 2639-2645.

[17] Jarret G, Cozannet P, Martinez J, Dourmad JY. Effect of different quality wheat dried distiller's grain soluble (DDGS) in pig diets on composition of excreta and methane production from faeces and slurry. Livest Sci 2011; 140: 275-282.

[18] Pedersen MB, Dalsgaard S, Knudsen KEB, Yu S, Lærke HN. Compositional profile and variation of distillers dried grains with soluble from various origins with focus on non-starch polysaccharides. Anim Feed Sci Technol 2014;197:130-141.

[19] Rasco BA, Dong FM, Hashisaka AE, Gazzaz SS, Downey SE, San Buenaventura ML. Chemical composition of distiller's dried grains with solubles (DDGS) from soft white wheat, hard red wheat and corn. J Food Sci 2006; 52: 236-237.

[20] Huan J, Liu K. Changes in composition and amino acid profile during dry grind ethanol processing from corn and estimation of yeast contribution towards DDGS proteins. J Agric Food Chem 2010; 58:3430-3437. 
826 [21] Linde M, Galbe M, Zacchi G. Bioethanol production from non-starch carbohydrate residues 827 in process streams from a dry-mill ethanol plant. Bioresour Technol 2008; 99: 6505-6511.

828 [22] Cookman DJ, Glatz CE. Extraction of protein from distiller's grain. Bioresour Technol 2009; 100:2012-2017.

830 [23] Anderson TJ, Ilankovan P, Lamsal BP. Two fraction extraction of $\alpha$-zein from DDGS and its 831 characterisation. Ind Crop Prod 2012;37:466-472.

832 [24] Liu KS. Fractionation of distillers dried grains with solubles (DDGS) by sieving and winnowing. Bioresour Technol 2009; 100: 6559-6569.

[25] Chang VS, Holtzapple MT. Fundamental factors affecting enzymatic reactivity. Appl 835 Biochem Biotechnol 2000, 5-37.

[26] Agbor VB, Cicek N, Sparling R, Berlin A, Levin DB. Biomass pretreatment: Fundamentals toward application. Biotechnol Adv 2011; 29: 675-685.

[27] Liu KS. Particle size distribution of distillers' dried grains with solubles (DDGS) and relationships to compositional and color properties. Bioresour Technol 2008; 99: 1303-1310.

[28] Srinivasan R, Dien BS, Rausch KD, Tumbleson ME, Singh V. Fiber separated from distillers 841 dried grains with solubles as a feedstock for ethanol production. Cereal Chem. 2007, 84: 563566.

[29] Srinivasan R, To F, Columbus E. Pilot scale fiber separation from distillers dried grains with solubles (DDGS) using sieving and air classification. Bioresour Technol 2009;100: 35483555 .

[30] Jönsson LJ, Alriksson B, Nilvebrant NO. Bioconversion of lignocelluloses: inhibitors and detoxification. Biotechnol Biofuels 2013;6:1-16.

[31] Menon V, Rao M. Trends in bioconversion of lignocellulose: Biofuels, platform chemicals \& biorefinery concept. Prog Energ Comb Sci 2012; 38: 522-550. 
[32] Balan V, Bals B, Chundawat SPS, Marshall D, Dale BE. Lingocellulosic biomass pretreatment using AFEX. In. Biofuels, Humana Press, pp. 61-77.

[33] Bals B, Balan V, Dale B. Integrating alkaline extraction of proteins with enzymatic hydrolysis of cellulose from wet distiller's grains and soluble. Bioresour Technol 2009; 100:5876-5883.

[34] Dien BS, Ximenes EA, O’Bryan PJ, Moniruzzaman M, Li XL, Balan V, Dale B, Cotta MA. Enzyme characterization for hydrolysis of AFEX and liquid hot-water pretreated distillers' grains and their conversion to ethanol. Bioresour Technol 99; 5216-5225.

[35] Kim Y, Hendrickson R, Mosier NS, Ladisch MR, Bals B, Balan V, Dale BE. Enzyme hydrolysis and ethanol fermentation of liquid hot water and AFEX pretreated distillers' grains at high-solids loading. Bioresour Technol 2008; 99; 5206-5215.

[36] Mosier N, Wyman CE, Dale BE, Elander R, Lee YY, Holtzapple M, Ladisch M. Features of promising technologies for pretreatment of lignocellulosic biomass. Bioresour Technol 2005; 96:673-678.

[37] Carvalheiro F, Duarte LC, Gírio FM. Hemicellulose biorefineries: a review on biomass pretreatments. J Sci Ind Res 2008; 67: 849-864.

[38] Ho AL, Carvalheiro F, Duarte LC, Roseiro LB, Charalampopoulos D, Rastall RA. Production and purification of xylooligosaccharides from oil palm empty fruit bunch fibre by a nonisothermal process. Bioresour Technol 2014; 152: 526-529.

[39] Nabarlatz D, Ebringerová A, Montané D. Autohydrolysis of agricultural by-products for the production of xylo-oligosaccharides. Carbohyd Polym 2007; 69: 20-28.

[40] Samala A, Srinivasan R, Yadav M.P, Kim T J, Prewitt L. (2012). Xylo-oligosaccharides production by autohydrolysis of corn fiber separated from DDGS. BioResources 2012;7: 3038-3050. 
874 [41] Mosier NS, Hendrickson R, Brewer M, Ho N, Sedlak M, Dreshel R, Welch G, Dien BS, 875 Aden A, Landisch MR. Industrial scale-up of $\mathrm{pH}$-controlled liquid hot water pretreatment of corn fiber for fuel ethanol production. App Biochem Biotechnol 2005a; 125:77-97.

877 [42] Saha BC, Iten LB, Cotta MA, Wu YV. Dilute acid pretreatment, enzymatic saccharification 878 and fermentation of wheat straw to ethanol. Process Biochem 2005; 40: 3693-3700.

879 [43] Taherzadeh MJ, Karimi K. Acid-based hydrolysis processes for ethanol form lignocellulosic 880

[44] Noureddini H, Byun J, Y TJ. Stagewise dilute-acid pretreatment and enzyme hydrolysis of distillers' grains and corn fiber. Appl Biochem Biotechn 2009; 159: 553-567.

[45] Noureddini H, Byun J. Dilute-acid pretreatment of distillers' grains and corn fiber. Bioresour 884

[46] Tucker MP, Nagle NJ, Jennings EW, Ibsen KN, Aded A, Nguyen QA, Kim KH, Noll SL. 886

[48] Sun Y. Cheng, J. Hydrolysis of lignocellulosic materials for ethanol production: a review.

[49] Mood SH, Golfeshan AH, Tabatabaei M, Jouzani GS, Najafi GH, Gholami M, Ardjimand M.

[50] Doner LW, Hicks, KB. Isolation of hemicellulose from corn fiber by alkaline hydrogen peroxide extraction. Cereal Chem 1997;74:176-181. Lignocellulosic biomass to bioethanol, a comprehensive review with a focus on pretreatment.

[51] Gáspár M, Juhász T, Szengyel Zs, Réczey K. Fractionation and utilisation of corn fibre carbohydrates. Process Biochem 2005;40:1183-1188. 
899 [52] Xiang Z, Watson J, Tobimatsu Y, Runge T. Film-forming polymers from distiller's grains: $900 \quad$ structural and material properties. Ind Crop Prod 2014;59:282-289.

901 [53] Xiang Z, Runge T. Co-production of feed and furfural from dried distillers' grains to improve $902 \quad$ corn ethanol profitability. Ind Crops Prod 2014; 55:207-216.

903 [54] Bayer EA, Chanzy H, Lamed R, Shoham Y. Cellulose, cellulases and cellulosomes. Curr 904 905 Opin Struct Biol 1998; 8:548-557.

[55] Van Dyk JS, Pletschke BI. A review of lignocelluloses bioconversion using enzymatic hydrolysis and synergistic cooperation between enzymes-Factors affecting enzymes, conversion and synergy. Biotechnol Adv 2012; 30: 1458-1480.

908 [56] Gilbert HJ, Hazlewood GP. Bacterial cellulases and xylanases. J Gen Microbiol 1993; 909 139:187-194.

[57] Mussatto SI, Fernandes M, Milagres AMF, Roberto IC. Effect of hemicellulose and lignin on enzymatic hydrolysis of cellulose from brewer's spent grain. Enz Microb Technol 2008; 43:124-129.

[58] Ximenes E, Kim Y, Mosier N, Dien B, Ladisch M. Inhibition of cellulases by phenols. Enz 914 Microb Technol 2010; 40: 170-176.

[59] Xu W, Reddy N, Yang Y. Extraction, characterization and potential applications of cellulose Biotech Biofuel 2010a; 3:22.

[61] Du C, Campbell GM, Misailidis N, Mateos-Salvador F, Sadhukhan J, Mustafa M, Weightman RM. Evaluating the feasibility of commercial arabinoxylan production in the 
context of a wheat biorefinery principally producing ethanol. Part 1. Experimental studies of arabinoxylan extraction from wheat bran. Chem Eng Res Des 2009; 87:1231-1238.

[62] Kwiatkowski JR, McAloon AJ, Taylor F, Johnston DB. Modeling the process and costs of fuel ethanol production by the corn dry-grind process. Ind Crop Prod 2006; 23:288-296.

[63] Mitra D, Rasmussen ML, Chand P, Chintareddy VR, Yao L, Grewell D, Verkade JG, Wang T, van Leeuen J. Value-added oil and animal feed production from corn-ethanol stillage using the oleaginous fungus Mucor circinelloides. Bioresour Technol 2012; 107: 368-375.

[64] Liang Y, Zhao X, Strait M, Wen Z. Use of dry-milling derived thin stillage for producing eicosapentaenoic acid (EPA) by the fungus Pythium irregulare. Bioresour Technol 2012; 111: 404-409.

[65] Hahn-Hagerdal B, Galbe M, Gorwa-Grauslund MF, Linden G, Zacchi G. Bio-ethanol-the fuel of tomorrow from the residues of today. Trends Biotechnol 2006; 24:549-556.

[66] Olson DG, McBride JE, Shaw AJ, Lynd LR. Recent progress in consolidated bioprocessing. Curr Opin Biotech 2012; 23:396-405.

[67] Xu W, Reddy N, Yang Y. Extraction, characterization and potential applications of cellulose in corn kernels and Distillers' dried grains with solubles (DDGS). Carb Polymers 2009;76:521-527.

[68] Sakamoto T, Hasunuma T, Hori Y, Yamada R, Kondo A. Direct ethanol production from hemicellulosic materials of rice straw by use of an engineered yeast strain codisplaying three types of hemicellullolytic enzymes on the surface of xylose-ulitizing Saccharomyces cerevisiae cells. J Biotech 2012; 158:203-210.

[69] Hasunuma T, Kondo A. Consolidated bioprocessing and simultaneous saccharification and fermentation of lingocellulose to ethanol with thermotolerant yeast strains. Process Biochem 2012;47:1287-1294. 
947 [70] Jin M, Balan V, Gunawan C, Dale BE. Consolidated bioprocessing (CBP) performance of 948 Clostridium phytofermentans on AFEX-treated corn stover for ethanol production. Biotechnol $949 \quad$ Bioeng 2011; 108:1290-1297.

950 [71] Gonzalez R, Campbell P, Wonf M. Production of ethanol from thin stillage by metabolically $951 \quad$ engineered Escherichia coli. Biotechnol Lett 2010; 32:405-411.

952 [72] Kim Y, Mosier N, Ladisch MR. Process simulation of modified dry grind ethanol plant with 953 recycle of pretreated and enzymatically hydrolysed distiller's grains. Bioresour Technol 2008; $954 \quad 99: 5177-5192$.

955 [73] Timilsina GR, Shrestha A. How much hope should we have for biofuels? Energy $956 \quad 2011 ; 36: 2055-2069$.

957 [74] Perkis D, Tyner W, Dale R. Economic analysis of a modified dry grind ethanol process with 958 recycle of pretreated and enzymatically hydrolyzed distillers' grains. Bioresour Technol $959 \quad 2008 ; 99: 5243-5249$.

960 [75] Leung CCJ, Cheung ASY, Zhang AYZ, Lam KF, Lin CSK. Utilisation of waste bread for 961 fermentative succinic acid production. Biochem Eng J 2012;65:10-15.

962 [76] Lam KF, Leung CCJ, Lei HM, Lin CSK. Economic feasibility of a pilot-scale fermentative $963 \quad$ succinic acid production from bakery wastes. Food Biopr Proc 2014;92:282-290.

964 [77] Lee PC, Lee WG, Kwon S, Lee SY, Chang HN. Succinic acid production by 965 966 967 [78] Zheng P, Fang L, Xu Y, Dong JJ, Ni Y, Sun ZH. Succinic acid production from corn stover 968 by simultaneous saccharification and fermentation using Actinobacillus succinogenes. $969 \quad$ Bioresour Technol 2010;101:7889-7894. 
970 [79] Kim DY, Yim SC, Lee PC, Lee WG, Lee SY, Chang HN. Batch and continuous fermentation 971 of succinic acid from wood hydrolysate by Manheimia succiniproducens MBEL55E. Enzyme $972 \quad$ Microb Technolol 2004;35: 648-653.

973 [80] Ceresana. Market Study: Bioplastics ( $3^{\text {rd }}$ Edition). 2013

974 [81] Verlinden RAJ, Hill DJ, Kenward MA, Williams CD, Radecka I. Bacterial synthesis of 975 biodegradable polyydroxyalkanoates. J Appl Microbiol 2007; 102:1437-1449.

976 [82] Wang Y, Yin J, Chen GQ. Polyhydroxyalkanoates, challenges and opportunities. Curr Op $977 \quad$ Biotech 2014; 30:59-65.

978 [83] Ramsay JA, Hassan MCA, Ramsay BA. Hemicellulose as a potential substrate for production 979 of poly( $\beta$-hydroxyalkanoates). Can J Microb 1995;41:262-266.

980 [84] Young FK, Kastner JR, May SW. Microbial production of poly- $\beta$-hydroxybutyric acid from 981 d-xylose and lactose by Pseudomonas cepacia. Appl Environ Microbiol 1994;60:4195-4198.

982 [85] Wu Q, Huang H, Hu G, Chen J, Ho KP, Chen GQ. Production of poly-3-hydroxybutyrate by 983 Bacillus sp. JMa5 cultivated in molasses media. Antonie van Leuuwenhoek 2001; 80:111$984 \quad 118$.

985 [86] Koutinas AA, Xu Y, Wang R, Webb C. Polyhydroxybutyrate production from a novel 986 feedstock derived from a wheat-based biorefinery. Enz Micr Technol 2007;40:1035-1044

987 [87] Ryu HW, Hahn SK, Chang YK, Chang HN. Production of poly(3-hydroxybutyrate) by high 988 cell density fed-batch culture of Alcaligenes eutrophis with phosphate limitation. Biotechnol $989 \quad$ Bioeng 1997;55:28-32.

990 [88] Lasprilla AJR, Martinez GAR, Lunelli BH, Jardini AL, Filho RM. Poly-lactic acid synthesis 991 for application in biomedical devices-A review. Biotechnol Adv 2012;30:321-328.

992 [89] Gao C, Ma C, Xu P. Biotechnological routes based on lactic acid production from biomass. 993 Biotechnol Adv 2011;29:930-939. 
[90] Ye L, Zhou X, Hudari MSB, Li Z, Wu JC. Highly efficient production of L-lactic acid from xylose by newly isolated Bacillus coagulans C106. Bioresour Technol 2013; 132:38-44.

[91] Tsuge Y, Kawaguchi H, Sasaki K, Tanaka T, Kondo A. Two-step production of D-lactate from mixed sugars by growing and resting cells of metabolically engineered Lactobacillus plantarum. Appl Microbiol Biotechnol. 2014;98:4911-4918.

[92] Izydorczyk MS, Biliaderis CG. Cereal arabinoxylans: advances in structure and physicochemical properties. Carbohyd Polym 1995; 28: 33-48.

[93] Saulnier L, Sado PE, Branlard G, Charmet G, Guillon F. Wheat arabinoxylans: Exploiting variation in amount and composition to develop enhanced varieties. J Cereal Sci 2007; 46:261-281.

[94] Gebruers K, Dornez E, Boros D, Fraś A., Dynkowska W, Bedő Z, Rakszegi M, Delcour JA., Courtin C.M. Variation in the content of dietary fiber and components thereof in wheats in the HEALTHGRAIN diversity screen. J Agri Food Chem 2008;56:9740-9749.

[95] Gibson GR, Probert HM, Loo JV, Rastall RA, Roberfroid MB. Dietary modulation of the human colonic microbiota: updating the concept of prebiotics. Nutr Res Rev 2004; 17:259275.

[96] Childs CE, Röytiö H, Alhoniemi E, Fekete AA, Forssten SD, Hudjec N, Lim YN, Steger CJ, Yaqoob P, Tuohy KM, Rastall RA, Ouwehand AC, Gibson GR. Xylo-oligosaccharides alone or in symbiotic combination with Bifidobacterium animalis subsp. lactis induce bifidogenesis and modulate markers of immune function in healthy adults: a double-blind, placebocontrolled, randomised, factorial cross-over study. Brit J Nut 2014; 11:1945-1956.

[97] Zhang Z, Smith C, Li W. Extraction and modification technology of arabinoxylans from cereal by-products: A critical review. Food Res Int 2014; 65: 423-436. 
1017 [98] Kayserilioğlu BŞ, Bakir U, Yilmaz L, Akkaş N. Use of xylan, an agricultural by-product, in 1018 wheat gluten based biodegradable films: mechanical, solubility and water vapor transfer rate 1019 properties. Bioresour Technol 2003; 89:239-246.

1020 [99] Shewry PR, D'Ovidio R, Lafiandra D, Jenkins JA, Mills ENC, Békés F, Khan K. Wheat grain 1021 proteins, In: Khan K, Shewry PR, editors. Wheat: chemistry and technology, 4th edition, AACC: St. Paul, MN, 2009. p. 223-298.

1023 [100] Shewry PR. The synthesis, processing and deposition of gluten proteins in the developing $1024 \quad$ wheat grain. Cereal Food World 1999; 44:587-589.

1025 [101] Shewry PR, Halford NG. Cereal seed storage proteins: structures, properties and role in 1026 grain utilisation. J Exp. Bot. 2002;53:947-958.

1027 [102] Paraman I, Lamsal BP. Recovery and characterisation of a-zein from corn fermentation 1028 coproducts. J Agri Food Chem 2011;59:3071-3077.

1029 [103] Bandara N, Chen L, Wu J. Protein extraction from triticale distillers grains. Cereal Chem $1030 \quad 2011 ; 88: 553-559$.

1031 [103] Ramsay JA, Hassan MCA, Ramsay BA. Hemicellulose as a potential substrate for 1032 production of poly( $\beta$-hydroxyalkanoates). Can J Microb 1995;41:262-266.

1033 [104] Xu W, Reddy N, Yang Y. An acidic method of zein extraction from DDGS. J Agric Food $1034 \quad$ Chem 2007;55:6279-6284.

1035 [105] Day L, Augustin MA, Batey IL, Wrigley CW. Wheat-gluten uses and industry needs. Trend $1036 \quad$ Food Sci Tech 2006; 17:80-90.

1037 [106] Shukla R, Cheryan M. Zein: the industrial protein from corn. Ind Crop Prod 2001; 13:171$1038 \quad 192$

1039 [107] Irissin-Mangata J, Bauduin G, Boutevin B, Gontard N. New plasticizer for wheat gluten $1040 \quad$ films. Eur Polym J 2001; 37:1533-1541. 
1041 [108] Kayserilioğlu BŞ, Stevels WM, Mulder WJ, Akkaş N. Mechanical and biochemical 1042 characterisation of wheat gluten films as a function of $\mathrm{pH}$ and co-solvent. Starch $1043 \quad 2001 ; 53: 381-386$

1044 [109] Sánchez AC, Popineau Y, Mangavel C, Larré C, Guéguen J. Effect of different plasticizers 1045 on the mechanical and surface properties of wheat gliadin films. J Agr Food Chem 1998; $1046 \quad 46: 4539-4544$

1047 [110] Cuq B, Gontard N, Guilbert S. Proteins as agricultural polymers for packaging production. $1048 \quad$ Cereal Chem 1998;75:1-9.

1049 [111] Wihodo M, Moraru CI. Physical and chemical methods used to enhance the structure and 1050 mechanical properties of protein films: A review. J Food Eng 2013; 114: 292-302.

1051 [112] Shaw NB, Monahan FJ, O’Riordan ED, O’Sullivan M. Physical properties of WPI films 1052 plasticized with glycerol, xylitol, or sorbitol. J Food Sci 2002; 67:164-167.

1053 [113] Morillon V, Debeaufort F, Blond G, Capelle M, Voilley A. Factors affecting the moisture 1054 permeability of lipid-based edible films: a review. Crit Rev Food Sci Nutr 2002; 42:67-89.

1055 [114] Larré C, Desserme C, Bardot J, Gueguen J. Properties of deaminated gluten films 1056 enzymaticaly cross-linked. J Agric Food Chem 2000; 48:5444-5449.

1057 [115] Roy S, Weller CL, Gennadios A, Zeece MG, Testin RF. Physical and molecular properties 1058 of wheat gluten films cast from heated film-forming solutions. J Food Sci 1999; 64:57-60.

1059 [116] Lee SL, Lee MS, Song KB. Effect of gamma-irradiation on the physicochemical properties 1060 of gluten films. Food Chem 2005; 92:621-625.

1061 [117] Inglett GE, Rose DJ, Stevenson DG, Chen D, Biswas A. Extracts for distillers dried grains 1062 with solubles with or without microwave irradiation. Cereal Chem 2009;86:661-664.

1063 [118] Luthria DL, Liu K, Memon AA. Phenolic acids and antioxidant capacity of distillers dried 1064 grains with solubles (DDGS) as compared with corn. J Am Oil Chem Soc 2012; 89:1297$1065 \quad 1304$ 
1066 [119] Luthria DL, Memon AA, Liu Keshun. Changes in phenolic acid content during dry-grind 1067 processing of corn into ethanol and DDGS. J Sci Food Agric 2014; 94:1723-1728.

1068 [120] Pedersen MB, Bunzel M, Schäfer J, Knudsen KEB, Sørensen JF, Yu S, Lærke HN. Ferulic 1069 Acid Dehydrodimer and Dehydrotrimer Profiles of Distiller's Dried Grains with Solubles 1070 from Different Cereal Species. J Agri Food Chem 2015; 63:2006-2012.

1071 [121] Maurya DK, Devasagayam TPA. Antioxidant and prooxidant nature of hydroxycinnamic 1072

1073 [122] Balasundram N, Sundram K, Samman S. Phenolic compounds in plants and agri-industrial 1074 by-products: Antioxidant activity, occurrence and potential uses. Food Chem 2006;99:1911075203.

1076 [123] Ou S, Kwok KC. Ferulic acid: pharmaceutical functions, preparation and applications in 1077

[126] Dervilly-Pinel G, Rimsten L, Saulnier R, Andersson R, Åman P. Water-extractable arabinoxylan from pearled flours of wheat, barley, rye and triticale. Evidence for the presence of ferulic acid dimers and their involvement in gel formation. J Cereal Sci 2001; 34:207-214.

[127] Faulds CB, Sancho AI, Bartolomé B. Mono- and dimeric ferulic acid release from brewer's spent grain by fungal feruloyl esterases. Appl Microbiol Biotechnol 2002; 60:489-493.

[128] Rosa NN, Dufour C, Lullien-Pellerin V, Micard V. Exposure or release of ferulic acid from wheat aleurone: impact on its antioxidant capacity. Food Chem 2013; 141; 2355-2362.

[129] Izadifar Z. Ultrasound pretreatment of wheat dried distiller's grain (DDG) for extraction of phenolic compounds. Ultrason Sonochem 2013;20:1359-1369. 
1091 [130] Winkler-Moser JK, Breyer L. Composition and oxidative stability of crude oil extracts of $1092 \quad$ corn germ and distillers grains. Ind Crop Prod 2011; 33:572-578.

1093 [131] Ezeji T, Blaschek HP. Fermentation of dried distillers' grains and soluble (DDGS) 1094 hydrolysates to solvents and value-added products by solventogenic clostridia. Bioresour $1095 \quad$ Technol 2008; 99: 5232-5242.

1096 [132] Leathers TD, Gupta SC. Production of pullulan from fuel ethanol byproducts by Aureobasidium sp. strain NRRL-12.974. Biotechnol Lett 1994; 14: 1163-1166.

[133] Rasmussen ML, Khanal SK, Pometto III AL, van Leeuwen J. Water reclamation and valueadded animal feed from corn-ethanol stillage by fungal processing. Bioresour Technol 2014; 151: $284-290$.

1101 [134] Wu JM, Liu RH. Thin stillage supplementation greatly enhances bacterial cellulose production by Gluconacetobacter xylinus. Carbohydrate Polymers 2012; 90: 116-121.

[135] Ahn JH, Sang BI, Um Y. Butanol production from thin stillage using Clostridium pasteurianum. Bioresour Technol 2011; 102: 4934-4937.

1107 [137] West T. Malic acid production from thin stillage by Aspergillus species. Biotechnol Lett 2011; 33: 2463-2467.

[138] Kang TS, Korber DR, Tanaka T. Bioconversion of glycerol to 1,3-propanediol in thin stillage-based media by engineered Lactobacillus panis PM1. J Ind Microbiol Biotechnol 2014; 41: 629-635.

[139] Djukić-Vuković A, Mojović LV, Jokić BM, Nikolić SB, Pejin JD. Lactic acid production on liquid distillery stillage by Lactobacillus rhamnosus immobilized onto zeolite. Bioresour Technol. 2013; 135: 454-458. 
1116 Figure legends:

1117

1118 Figure 1 Simplified schematic representation of a dry-mill bioethanol production process and by-product 1119 production streams

1120

1121 Figure 2 DDGS valorisation based on a conceptual biorefinery strategy

1122

1123

1124

1125

1126

1127

1128 


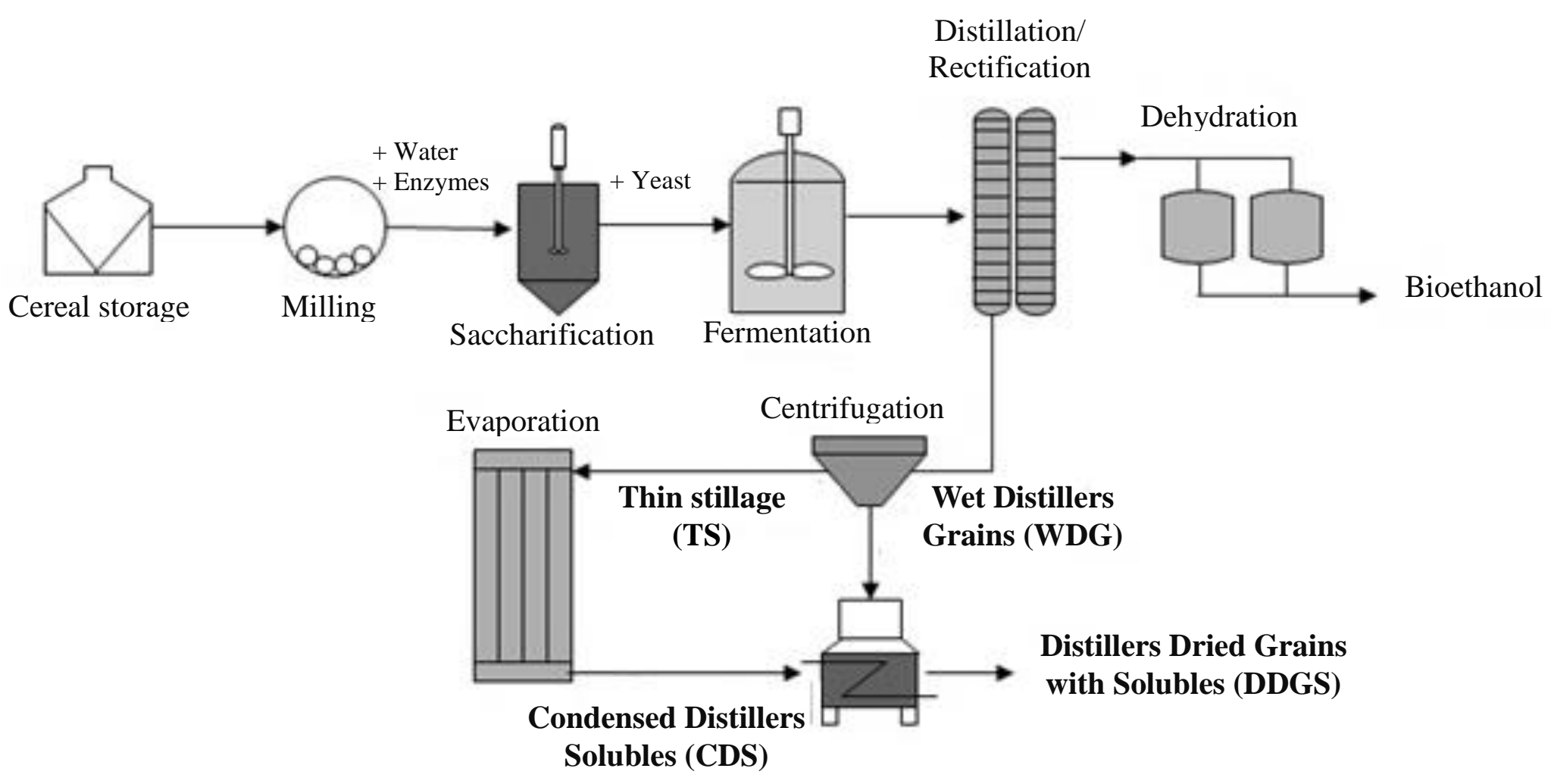




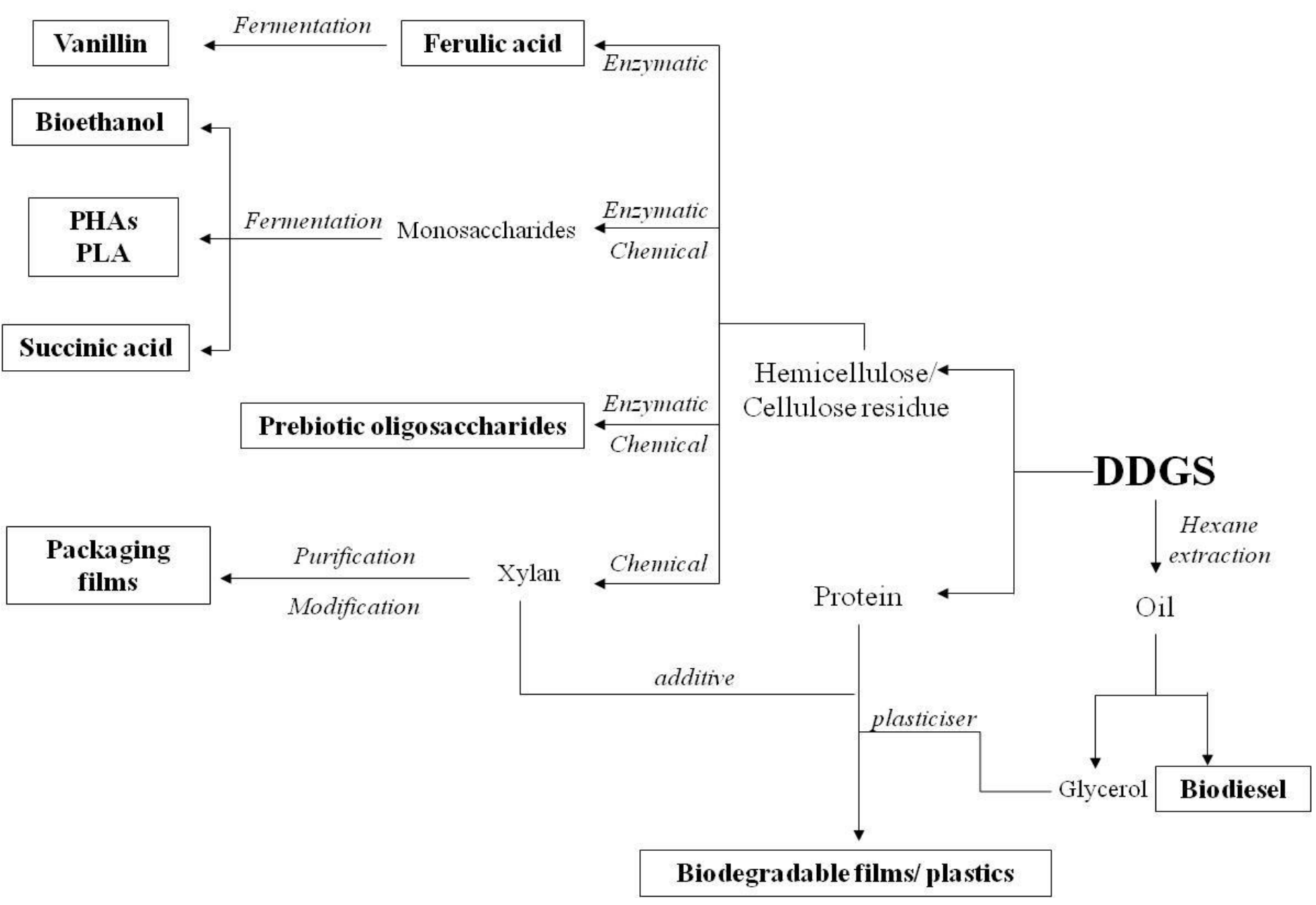

Fig. 2 
1140 Table 1. Composition of DDGS from different plants and sources (expressed in \%, dry matter basis)

\begin{tabular}{lllll}
\hline & \multicolumn{2}{l}{ Maize DDGS $^{[\mathbf{1 6}[}$} & Wheat DDGS & Distillery DDGS \\
\hline Dry matter & $87.2-90.2$ & $89.3-94.4$ & $90.5-92.7$ & Mixed DDGS $^{[18] \mathbf{a}}$ \\
Oil & $10.2-11.4$ & $3.6-5.6$ & $8.1-12.8$ & $87.3-92.6$ \\
Protein & $28.7-31.6$ & $32.6-38.9$ & $23.4-27.9$ & $33.8-38.3$ \\
Crude fibre & $8.3-9.7$ & $6.2-10.9$ & $9.6-10.6$ & $5.6-7.6$ \\
ADF & $13.8-18.5$ & $7.7-17.9$ & $15.4-19.3$ & $11.5-12.3$ \\
NDF & $36.7-49.1$ & $25.1-33.8$ & $34.8-40.3$ & $28.9-31.2$ \\
Ash & $5.2-6.7$ & $4.3-6.7$ & $3.4-7.3$ & $8.0-10.2$ \\
\hline
\end{tabular}

1141 a: Parent grains of mixed DDGS were wheat, triticale, barley and rye. 
1143 Table 2. Summary of main products and yields from DDGS chemical pre-treatments

\begin{tabular}{|c|c|c|c|c|c|}
\hline Raw material & Treatment & Conditions & Main products & Yield & Reference \\
\hline Maize Distillers & Dilute acid & Acid conc. $1.0 \%$ & Monosaccharides & $61.3 \mathrm{~g} / 100 \mathrm{~g}$ & [45] \\
\hline \multirow[t]{2}{*}{ Grains } & hydrolysis & Solid load. $10 \%$ & (Xyl, Ara, Gluc, Gal) & carbohydrates & \\
\hline & & Temp. $140^{\circ} \mathrm{C}$ & & & \\
\hline \multirow[t]{3}{*}{ Maize DDGS } & Dilute acid & Acid conc. $3.1 \%$ & Monosaccharides & $43.4 \mathrm{~g} / 100 \mathrm{~g}$ & [47] \\
\hline & hydrolysis & Solid load. $15 \%$ & (Xyl, Ara, Gluc) & dry matter & \\
\hline & & Temp. $112^{\circ} \mathrm{C}$ & & & \\
\hline \multirow[t]{3}{*}{ Maize DDGS } & Three stage & Acid conc. $1 \%$ & Monosaccharides & $35.8 \mathrm{~g} / 100 \mathrm{~g}$ & [44] \\
\hline & dilute acid & Solid load. $15 \%$ & & carbohydrates & \\
\hline & hydrolysis & Temp. $120^{\circ} \mathrm{C}$ & & & \\
\hline \multirow[t]{2}{*}{ Maize DDGS fibre } & Autohydrolysis & Temp. $180^{\circ} \mathrm{C}, 15 \mathrm{~min}$ & Xylo-oligosaccharides & $18.6 \%(\mathrm{w} / \mathrm{w})$ of & [40] \\
\hline & & Solid load. $10 \%$ & & feedstock & \\
\hline \multirow[t]{2}{*}{ Maize DDGS } & Liquid hot water & Solid load. $15.7 \%$ & Monosaccharides & $86 \%$ Glu, $29 \%$ & {$[34]$} \\
\hline & & Temp. $160^{\circ} \mathrm{C}, 20 \mathrm{~min}$ & & Xyl, 37\% Ara & \\
\hline \multirow[t]{4}{*}{ Maize DDGS } & AFEX & Solid load. 25g & Monosaccharides & $93 \%$ Glu, $14 \%$ & [34] \\
\hline & & Ammonia load. $80 \%$ & & Xyl, 20\% Ara & \\
\hline & & Temp. $70^{\circ} \mathrm{C}$ & & & \\
\hline & & Pressure $350-430$ psi & & & \\
\hline
\end{tabular}


1147 Table 3. Enzymes involved in the degradation of cellulosic and hemicellulosic materials

\begin{tabular}{|c|c|c|c|}
\hline Category & Enzymes & Linkage hydrolysed & Products \\
\hline \multirow{7}{*}{ Cellulases } & Endo-1,4- $\beta$-glucanase & Internal $\beta-1,4$ & Cellobiose \\
\hline & Cellobiohydrolase & Terminal $\beta-1,4$ & Cellobiose \\
\hline & & (reducing end) & \\
\hline & Exo-1,4- $\beta$-glucanase & Terminal $\beta-1,4$ & Cellotetrose, Cellobiose \\
\hline & & (non-reducing end) & \\
\hline & $\beta$-glucosidase & Terminal $\beta-1,4$ & Glucose \\
\hline & & (non-reducing end) & \\
\hline \multirow{7}{*}{ Hemicellulases } & Endo-1,4- $\beta$-xylanase & Internal $\beta-1,4$ & Xylo-oligosaccharides \\
\hline & Exo-1,4- $\beta$-xylanase & Terminal $\beta-1,4$ & Xylose, xylobiose \\
\hline & & (reducing end) & \\
\hline & $\beta$-Xylosidase & Terminal $\beta-1,4$ & Xylose \\
\hline & & (non-reducing end) & \\
\hline & $\alpha$-L-Arabinofuranosidases & Terminal $\alpha-1,2 / \alpha-1,3 / \alpha-$ & Arabinose \\
\hline & & 1,5 (non-reducing end) & \\
\hline Accessory & $\alpha$-D-Glucuronidases & $\alpha-1,2$-glycosidic bond & Methylglucuronic acids \\
\hline xylanolytic & Acetyl xylan esterase & Acetyl ester bond & Acetic acid \\
\hline \multirow[t]{2}{*}{ enzymes } & Feruloyl esterase & Ester bond & Ferulic acid \\
\hline & $p$-Coumaroyl esterase & Ester bond & Coumaric acid \\
\hline
\end{tabular}


1151 Table 4. Enzyme combinations and main product yields from chemically pre-treated DDGS

\begin{tabular}{|c|c|c|c|c|}
\hline Raw material & Pre-treatment & Enzymes & Yields & Reference \\
\hline Maize DDGS & AFEX & $\begin{array}{l}\text { Cellulase (GC220), } \beta \text { - } \\
\text { glucosidase (Novo188), } \\
\text { multifect pectinase, feruloyl } \\
\text { esterase (Depol 740L) }\end{array}$ & $\begin{array}{l}91 \% \text { Glu, } 82 \% \text { Xyl, } 70 \% \text { Ara } \\
100 \% \text { Glu, } 81 \% \text { Xyl, } 98 \% \text {, Ara }\end{array}$ & [34] \\
\hline Maize DDGS & None & $\begin{array}{l}\text { Cellulase (Spezyme CP), } \beta \text { - } \\
\text { glucosidase (Novozyme 188) }\end{array}$ & $76 \%$ Glu & [35] \\
\hline Maize WDG & $\begin{array}{l}\text { LHW } \\
\text { AFEX }\end{array}$ & $\begin{array}{l}\text { Cellulase (GC220), } \beta \text { - } \\
\text { glucosidase (Novozyme 188), } \\
\text { Xylanase (Multifect Pectinase), } \\
\text { feruloyl esterase (Depol 740L) }\end{array}$ & $\begin{array}{l}\text { 77\% Glu, } 41 \% \text { Xy } \\
72 \% \text { Glu, } 45 \% \text { Xyl }\end{array}$ & [35] \\
\hline Maize DDGS & $\begin{array}{l}\text { Dilute acid } \\
\text { hydrolysis }\end{array}$ & $\begin{array}{l}\text { Cellulase } \& \beta \text {-glycosidase } \\
\text { (Sigma) }\end{array}$ & $80 \%$ Glu, $82 \%$ Xyl & [44] \\
\hline
\end{tabular}

$11 \overline{52}$

1153 
Table 5. Microbial conversions of DDGS-derived hydrolysates and thin stillage

\begin{tabular}{|c|c|c|c|c|c|}
\hline Feedstock & Microorganism & Carbon source & Product & Yield $^{\text {a }}$ & Reference \\
\hline Pre-treated & Clostridium acetobutylicum & Mixed sugars & $\mathrm{ABE}$ & $34 \%$ & [131] \\
\hline \multirow[t]{4}{*}{ DDGS } & Saccharomyces cerevisiae & Glucose-Xylose & Ethanol & $49 \%$ & [35] \\
\hline & Mucor circinelloides & Mixed sugars & Microbial oil & $46 \%^{b}$ & [63] \\
\hline & Aureobasidium sp. & Mixed sugars & Pullulan & $21 \%$ & [132] \\
\hline & Rhizopus oligosporus & Glycerol & Single cell protein & $43 \%$ & [133] \\
\hline Thin & Gluconacetobacter xylinus & Glucose & Bacterial cellulose & $57 \%$ & [134] \\
\hline \multirow[t]{5}{*}{ stillage } & Cl. pasteurianum & Glycerol & Butanol & $44 \%$ & {$[135]$} \\
\hline & Escherichia coli (recombinant) & Glycerol & Ethanol & $40 \%$ & [136] \\
\hline & Aspergillus niger & Glycerol-Mixed sugars & Malic acid & $80 \%$ & [137] \\
\hline & Lactobacillus panis (recombinant) & Glycerol- Glucose & 1,3-Propanediol & $74 \%$ & {$[138]$} \\
\hline & Lactobacillus rhamnosus & Mixed sugars & Lactic acid & $96 \%$ & [139] \\
\hline
\end{tabular}

$1156{ }^{\mathrm{a}}$ Expressed as \%, w/w of consumed substrate

$1157 \quad{ }^{\mathrm{b}}$ Expressed as \% w/w of produced biomass

1158 